\title{
IMPACT OF DAY LENGTH AND TOTAL PROTEIN CONTENT IN THE DIET OF FARMED FALLOW DEER (DAMA DAMA) ON THEIR PLASMA MINERAL LEVEL AND HAEMATOLOGICAL INDICES
}

\author{
TAJChMAN, K. ${ }^{1 *}$ - Bogdaszewski, M. ${ }^{2}$ - KowAlCZUK-VAsileV, E. ${ }^{3}$ - DĄBROWSKI, R. ${ }^{4}$ \\ ${ }^{I}$ Department of Ethology and Animal Welfare, Faculty of Biology, Animal Sciences and \\ Bioeconomy, University of Life Sciences in Lublin, Akademicka 13, 20-950 Lublin, Poland \\ ${ }^{2}$ Institute of Parasitology of the Polish Academy of Sciences, Research Station in Kosewo \\ Górne, 11-700 Mragowo, Poland \\ (e-mail: kosewopan@ kosewopan.pl; phone: +48-89-742-4380)
}

${ }^{3}$ Institute of Animal Nutrition and Bromatology, Faculty of Biology, Animal Sciences and Bioeconomy, University of Life Sciences in Lublin, Akademicka 13, 20-950 Lublin, Poland (e-mail: edyta.kowatczuk@up.lublin.pl; phone: +48-81-445-6914)

${ }^{4}$ Department and Clinic of Animal Reproduction, Faculty of Veterinary Medicine, University of Life Sciences in Lublin, Gtęboka 30, 20-612 Lublin, Poland (e-mail: roman.dabrowski@up.lublin.pl; phone: +48-81-445-6168)

*Corresponding author e-mail: katarzyna.tajchman@ @up.lublin.pl; phone: +48-81-445-6848

(Received $12^{\text {th }}$ Jun 2019; accepted $11^{\text {th }}$ Oct 2019)

\begin{abstract}
Blood is the main carrier of nutrients and the first indicator of changes occurring in an organism. Hence, the aim of the study was to demonstrate the effect of the day length and the total protein content in the diet for farmed fallow deer (Dama dama) on the selected mineral contents of the plasma and blood haematology. The investigation of farmed fallow deer revealed an increase in the level of red blood cells (RBC) and haemoglobin (HGB) induced by altered light conditions, which may the evidence stimulation of erythropoiesis by an increased concentration of androgens. The level of white blood cells (WBC) changed significantly in the control group, which was kept in the least favourable conditions, as indicated by leukocytosis. In the present study, animals exposed to a changed day length exhibited a significant increase in the plasma concentrations of most minerals (phosphorus - $\mathrm{P}$, magnesium - Mg, copper - $\mathrm{Cu}$, calcium - $\mathrm{Ca}$, iron - $\mathrm{Fe}$ ) after the winter period in the first year of studies, which indicates accelerated development of antlers in farmed fallow deer. However, there was no equally intensive increase in the plasma mineral content (except for $\mathrm{Ca}$ ) in the same group of animals in the second year of the study. This probably resulted from the administration of adequate nutrition, which prevented changes in the blood mineral concentration despite the antler growth.
\end{abstract}

Keywords: Dama dama, wintering conditions, photoperiodism, nutrition, haematology, minerals

\section{Introduction}

Blood is a living tissue composed of different cells which are suspended in the liquid part of the blood called plasma. Its components form a highly developed defense and transport system on which animal body health highly depend. It is, among others, a transporter of various compounds that provides cells with oxygen, nutrients, removes carbon dioxide and other unnecessary or harmful by-products of metabolism, but is also a carrier of hormones, chemical messenger substances, and thus participates in the transmission of information throughout the body. In addition, blood is involved in the 
regulation of body temperature, performs defense functions, protects against pathogens, cures the body - thanks to its coagulation properties (Weiss and Wardrop, 2010).

All this makes so blood is the main and the first indicator of changes occurring in the organism (Weiss and Wardrop, 2010). All factors that can affect an animal are reflected by basic blood tests. Adequate nutrition and enhanced light conditions are often used in farm breeding. The impact of the photoperiod and an appropriate composition of the feed ration have been extensively investigated in cervids, but insufficient attention has been devoted to the closely related fallow deer (Dama dama). It is difficult to find literature with data on the influence of an altered day length on the basic haematological parameters in European fallow deer. The day length is extremely important in the life of cervids (Jaczewski, 1954; Pollock, 1975) especially in their hormonal economy (Asher et al., 1989; Suttie et al., 1984; Sempere et al., 1992; Elliott et al., 1996), which may affect the basic haematological parameters.

One of the most important stages in the life of deer is the growth of the antlers regulated by among other things, the hormonal economy which is affected by the daily photoperiod as demonstrated by Jaczewski (1954). Goss (1969) subsequently demonstrated that acceleration of antler cycles can be induced by increasing the frequency of annual daylight cycles with up to four complete antler growth cycles being achieved in 12 months. Changes in food intake, behaviour and plasma hormone concentrations of red deer stags were also fully entrained to a 6-monthly photoperiod cycle (Goss, 1969).

Growing Cervids require an additional 14-20\% protein (Ullrey et al., 1967) especially during the growth of antlers. However, Dryden (2016) showed antler growth in adult stags is little affected by diet protein concentrations over $7 \%$, but supplements of protected protein or methionine may improve antler growth. Richardson et al. (2008) research has shown growing antlers consist almost entirely of protein (collagen) and typically consist of 35-45\% protein once they harden or "mineralize." While antlers are growing, bucks require a diet of 13-16\% protein for optimum development, along with other required nutrients. Only $6-10 \%$ protein is required for maintenance of adult deer (Richardson et al., 2008). Antler development in deer results from the collective contribution of nutrition, genetics and age (Ullrey, 1982). It was shown that, whitetailed deer require a diet containing 13 to $16 \%$ crude protein (including adequate levels of carbohydrates, fats, minerals and vitamins) in order to express their genetic potential for antler development. In the other studies showed wild cervids require roughly $5 \%$ crude protein of dry matter intake for maintenance, but up to $25 \%$ for reproduction (Dryden, 2011; Felton et al., 2018). Natural forage for northern cervids typically contains 5-15\% crude protein, with rare extremes of 25-30\% (Marell et al., 2006; Wam et al., 2016). The objective of protein diet and supplementation is therefore to provide additional nutrients to the deer's natural diet during times when native forage is thought to be inadequate in quantity or quality (especially winter months in the temperate climate zone). Moreover Felton et al. (2018) revealed a lack of evidence that cervids more strongly select for protein in summer than they do in winter. In addition, under farm conditions, the amount of feed consumed by cervids can be controlled only in winter (outside the pasture period).

It has been proven that changes in animal nutrition affect the basic haematological parameters and the concentration of minerals in the blood (Kováč et al., 1997). Also blood is a very sensitive indicator of metabolic changes in both the physiological and pathological status of animals (Weiss and Wardrop, 2010). Thus, the aim of the study 
was to demonstrate the effect of the day length and total protein content in the diet for farmed fallow deer on the plasma level of selected minerals and haematological blood indices.

\section{Materials and methods}

\section{Experimental design}

The research was carried out at the Research Station of the Institute of Parasitology, Polish Academy of Sciences, Kosewo Górne (Region of Warmia and Mazury; Poland; N: $53^{\circ} 48^{\prime}$; E: $\left.21^{\circ} 23^{\prime}\right)$. All analyses were performed with the consent of the Local Ethics Committee 0069, Resolution No. 42/2016. The study involved 36 male stags in the $3^{\text {rd }}$ $6^{\text {th }}$ year of life divided on an analogous basis into three equal groups $(n=12)$ receiving different nutrition and provided with different daily photoperiods in winter months (from January to the end of March 2016 and from December 2016 to the end of March 2017):

Experimental group I: Standard farm nutrition with a total protein level of $16 \%$ (each animal ingested on average $600 \mathrm{~g}$ of the mixture per day with the following composition: $70 \%$ of crushed oats in $15 \%$ of universal rapeseed concentrate (producer: Eko-pasz, Mońki, Poland) containing 33\% of crude protein and in $15 \%$ of universal soybean concentrate (producer: Eko-pasz, Mońki, Poland) with 45\% crude protein content). The diet included hay and grass silage provided ad libitum and a mineral feed mixture Opas Ekstra 7669 from LNB (producer: Cargill, Polska) (Table 1). The supplement constituted $2.5 \%$ of the standard farm nutrition - $15 \mathrm{~g}$. The experimental group I animals were kept on a run between 7:00 and 15:00 and spent the rest of the day inside the shelter; they were exposed to the natural length of the daylight.

Table 1. Composition of the diet supplement provided to all groups farmed fallow deer

\begin{tabular}{|c|c|c|}
\hline Premix composition & Components & Content (in 1 kg) \\
\hline \multirow{4}{*}{ Macronutrients (\%) } & Calcium (Ca) & 21 \\
\hline & Phosphorus (P) & 3 \\
\hline & Sodium $(\mathrm{Na})$ & 10 \\
\hline & Magnesium (Mg) & 4 \\
\hline \multirow{7}{*}{ Micronutrients (mg) } & Manganese (Mn) & 3000 \\
\hline & Zinc $(\mathrm{Zn})$ & 6000 \\
\hline & Iron $(\mathrm{Fe})$ & 4000 \\
\hline & Copper $(\mathrm{Cu})$ & 1000 \\
\hline & Cobalt (Co) & 25 \\
\hline & Iodine (I) & 100 \\
\hline & Selenium (Se) & 25 \\
\hline \multirow{4}{*}{ Vitamins } & A (j.m.) & 500000 \\
\hline & D3 (j.m.) & 100000 \\
\hline & $\mathrm{E}(\mathrm{mg})$ & 1000 \\
\hline & $\mathrm{B} 1$ (mg) & 4000 \\
\hline
\end{tabular}


Experimental group II: Nutrition was identical as in the experimental group I. Group II was subjected to changed photoperiod conditions, i.e. the day length was artificially prolonged in relation to natural conditions. The experimental group II animals were kept on a run adjacent to the shelter between 7:00 and 15:00 and spent the rest of the day inside. The shelter was equipped with electric LED lamps with a nominal power of $18 \mathrm{~W}$ and a declared light stream of 1850 lumens. The emitted light was cold white (colour temperature $6000 \mathrm{~K}$ ). Light intensity in the shelter and outside was measured using an AB-8809A luxometer (producer: Abatronic, Radom, Poland).

In accordance with the adopted assumptions, the day length was extended by illumination of the shelter from January to the end of March 2016 and from December to the end of March 2017. Unfortunately, the same length of the artificial illumination plan was not used in both years, because in the first one the work associated with the breeding treatment performed annually was delayed by a month. The light in the shelter was turned on and off automatically. The comparison of the length of the natural daylight and the applied photoperiod regime are presented in Figure 1.

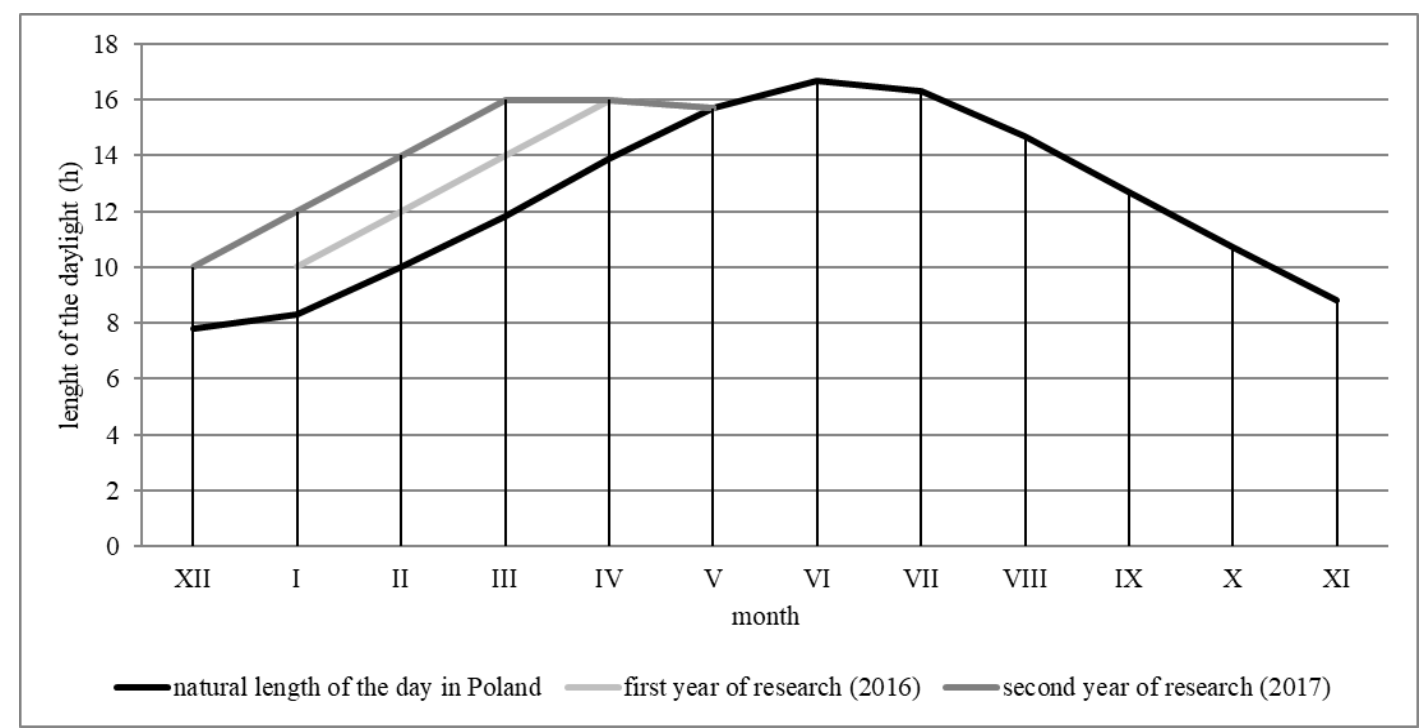

Figure 1. Comparison of the natural day length in Poland and the photoperiod regime in 2016 and 2017

Control group III: Standard farm nutrition with a total protein content of $10 \%$. The diet included hay and grass silage provided ad libitum and a mineral feed mixture Opas Ekstra 7669 from LNB (producer: Cargill, Poland) (Table 1). The supplement constituted $2.5 \%$ of the standard farm nutrition $-15 \mathrm{~g}$. The group was kept on a run throughout the day and exposed to the natural length of the daylight.

\section{Observations and measurements}

The animals from groups I and II spent the winter (December - March) under a shelter situated in the wintering ground divided into two identical rooms so that it was possible to control the amount of consumed feed. The walls of the shelter were constructed of horizontal wooden boards and provided protection against the adverse impact of weather conditions. Under the shelter, there was a feeding rack for haylage, water containers, and feeding troughs for concentrated feed. The concentrate was 
provided once daily. The animals had free access to water over the entire winter period. After the winter period, the animals stayed on the available pasture without supplementation (April - October) (Fig. 2). Body weight was measured with the use of a set of MP 800 sensors coupled with a Tru-Test DR 3000 weight reader LNB (producer: Tru-Test Group, Auckland, New Zealand). As declared by the manufacturer, the accuracy of this set is $+/-1 \%$ and the minimum resolution is $100 \mathrm{~g}$.

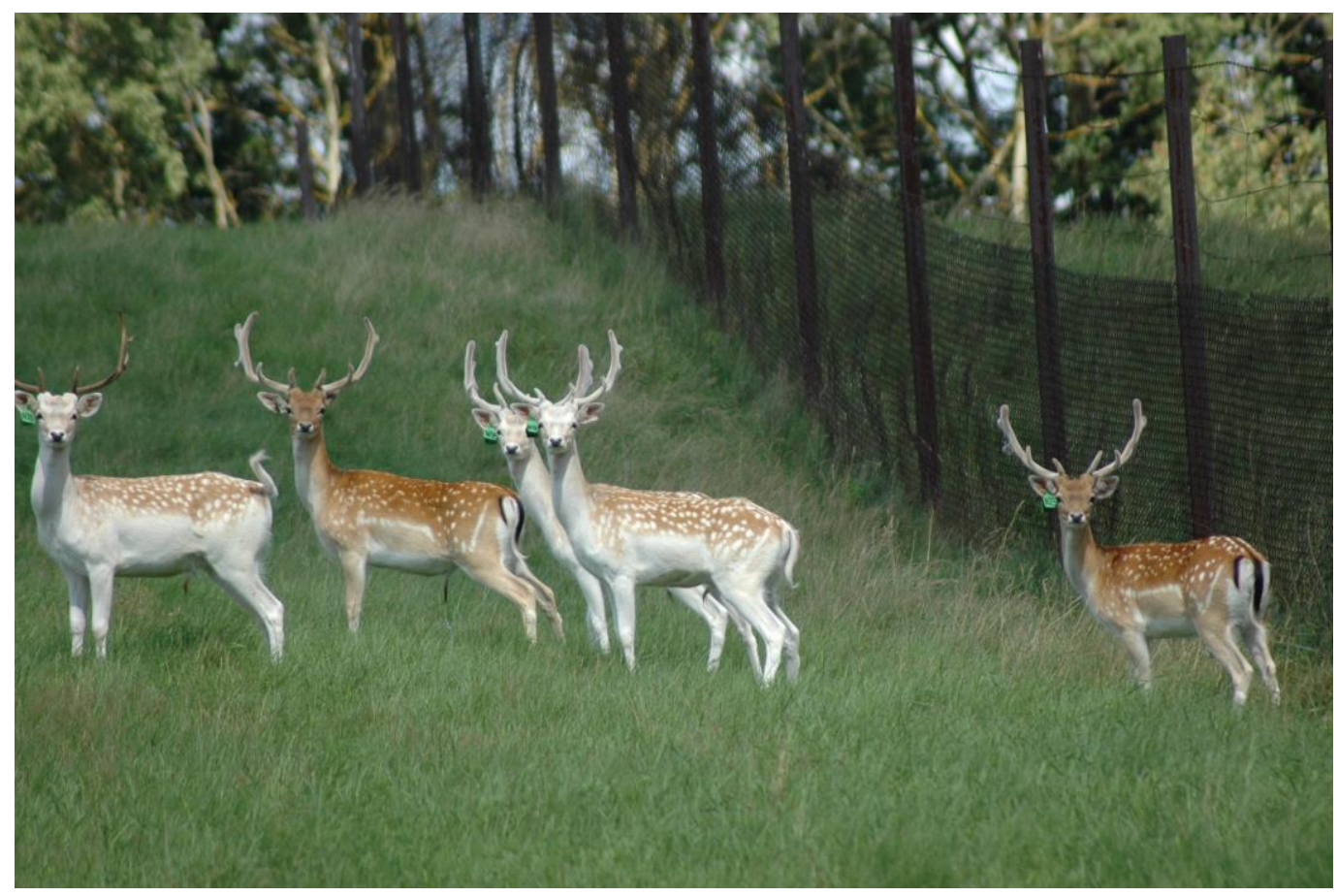

Figure 2. Farm fallow deer during the pasture period

In accordance with the routine zootechnical practice adopted on the farm, antlers were cut at a height of $1 \mathrm{~cm}$ above the rose, which is the minimum height in technical terms. This treatment not only does not affect the welfare of experimental animals but also enhances their safety during the mating season, as a high density of relatively large groups of males on farms with limited space increases the risk of serious injuries and even deaths. After removal of dried velvet and mineral impurities and after final drying (in natural conditions) for 30 days, the antlers were weighed (each beam separately) on an electronic balance WLC F1/K with an accuracy of +/- $0.5 \mathrm{~g}$ (producer: Radwag, Poland).

\section{Sampling}

Samples were collected while the fallow deer were standing inside a small handling box $(2 \mathrm{~m} \times 2 \mathrm{~m} \times 0.6 \mathrm{~m})$ (Fig. 3) with no need of sedation. Blood samples were collected from vena jugularis externa always at the same time (from 1 to $3 \mathrm{~h}$ after dawn) to avoid variations associated with circadian rhythms as in research of GásparLópez et al. (2011). For haematological analyses, 5-ml blood samples were collected into vacuum tubes containing an anticoagulant agent (EDTA) and into tubes with heparin as an anticoagulant. The samples were chilled $\left(4-8{ }^{\circ} \mathrm{C}\right)$ within $15 \mathrm{~min}$ after collection. Haematological analysis was carried out within 2 or $3 \mathrm{~h}$ after extraction with the use of an automated haematological analyzer Mythic 18 (producer: Orphee S.A., 
Switzerlan). The device was calibrated each time before the analysis of the samples. The blood was analysed for the content of white blood cells (WBC), red blood cells (RBC), haemoglobin (HGB), and haematocrit (HCT).

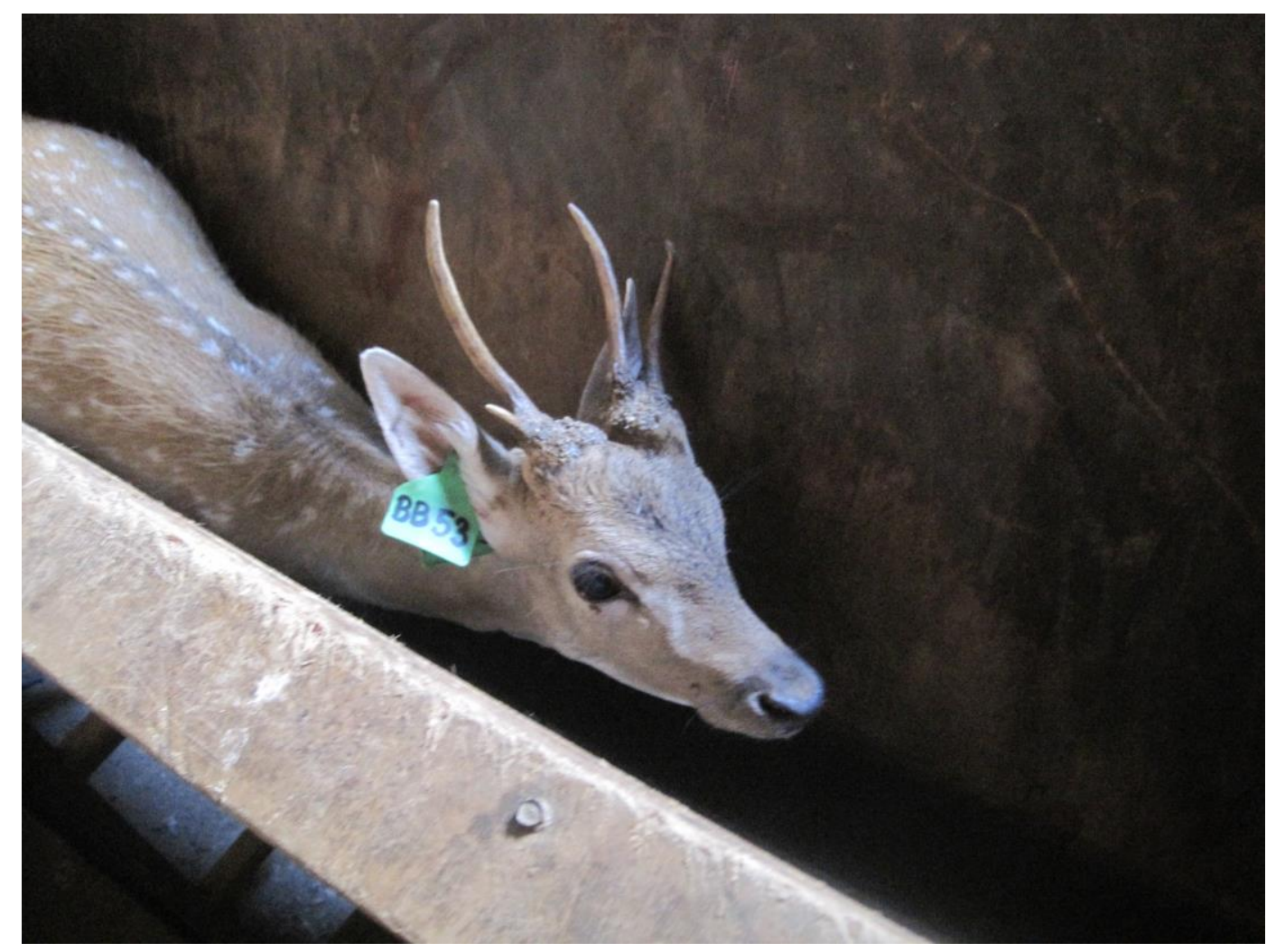

Figure 3. Farm fallow deer in the handling box

Concurrently, plasma for analysis of the biochemical parameters was obtained by centrifugation of whole blood at $3000 \mathrm{rpm}$ for $10 \mathrm{~min}$ in a laboratory centrifuge MPW350R (producer: MPW Medical Instruments, Warsaw, Poland) at a temperature of $4{ }^{\circ} \mathrm{C}$. After centrifugation, plasma zinc $(\mathrm{Zn})$, phosphor $(\mathrm{P})$, magnesium $(\mathrm{Mg})$, copper $(\mathrm{Cu})$, calcium $(\mathrm{Ca})$, iron $(\mathrm{Fe})$ levels were determined using reagent kits (BioMaxima, Lublin, Poland) according to the manufacturer's protocols and a random access biochemical analyser Metrolab 2300 GL (producer: Metrolab SA, Buenos Aires, Argentina).

The haematological parameters and the plasma content of selected minerals were determined in two terms: before and after the winter in 2016 and 2017, because in these times all animals were kept in the handling box and where weighed. After the procedure, they are moved to a suitable room (before winter) depending on the group to which they belong or to the pasture (after winter). The article is part of a cycle of research of farmed fallow deer. These animals have participated too in study in which we examined some hematological parameters (Tajchman, 2019).

\section{Statistical analysis}

The results were analysed statistically. The values were presented as a mean value and standard deviation in the case of measurable parameters and as cardinality and percentage in the case of non-measurable variables. 
The normality of the distribution of variables in the analysed groups was verified with the Shapiro-Wilk test. The differences between the two measurement terms were assessed with the Student's t-test or with the Mann-Whitney test for dependent samples and with the paired-samples Wilcoxon test when the conditions for application of the former test were not met. The differences between the three experimental groups were evaluated with the ANOVA analysis of variance and the post-hoc RIR Tukey test. When the conditions for application of the former analysis were not fulfilled, the Kruskal-Wallis test was used. In order to analyze the interaction of the effect of various factors (diet, lighting, time/year), a mixed multivariate ANOVA analysis of variance was performed. In the case of sphericity disorders (tested by the Meuchly test), the Greenhouse-Geisser correction was applied to the $F$ statistics. A significance level of $P<0.05$ was assumed, which indicated the presence of statistically significant differences or correlations. The database was compiled and statistical analyses were carried out in the Statistica 9.1 software (StatSoft, Polska).

\section{Results}

The investigations consisted in comparison of the haematological parameters and mineral concentration in the blood plasma of the farmed fallow deer assessed before the winter period in the first year (2016) of the study and before the winter period in the second year (2017). There was a significant decline from 5.288 to $3.638 \times 10^{9} \mathrm{~L}^{-1}$ $(P=0.041)$ in WBC in group $\mathrm{I}$ and on average from 14.397 to $11.564 \times 10^{12} \mathrm{~L}^{-1}$ $(P<0.05)$ in $\mathrm{RCB}$ in all experimental groups (Table 2$)$. In turn, the $\mathrm{Zn}$ content increased significantly, on average by $19.11 \mu \mathrm{mol} \mathrm{L}^{-1}(P<0.05)$, in all groups. The highest increase, i.e. by $30.559 \mathrm{umol} \mathrm{L}^{-1}$ was noted in group I. A significant increase by $0.267(P=0.034)$ in the plasma $\mathrm{P}$ content was noted in group $\mathrm{I}$, while the level of $\mathrm{Mg}$ increased by $0.174 \mathrm{mmol} \mathrm{L}^{-1}(P=0.0015)$ in group II. The plasma Ca content increased significantly in all study groups assessed in the pre-wintering period in 2016 and 2107, with the highest increase by $0.685(P<0.05)$ observed in the control group. The Fe concentration also increased significantly in all groups, and the highest increase was noted in group II, i.e. by $13.046(P=0.004)$ (Table 2$)$.

A statistical analysis of differences between the haematological parameters and the plasma mineral content recorded after the winter period in the first (2016) and second (2017) years of the study was carried out. The data showed a significant increase by $0.657 \times 10^{9} \mathrm{~L}^{-1}(P=0.049)$ in $\mathrm{WBC}$ only in the control group and a significant reduction of $\mathrm{RBC}$, on average by $2.404 \times 10^{12} \mathrm{~L}^{-1}(P<0.05)$, in all groups (Table 3). The plasma $\mathrm{Zn}$ concentration increased in group I and in the control, with a higher value in the control group (III), i.e. by 16.970 umol $\mathrm{L}^{-1}(P<0.05)$. The plasma $\mathrm{P}$ concentration declined on average by $0.875 \mathrm{mmol} \mathrm{L}^{-1}(P<0.05)$ after the winter period. There was a significant reduction on the $\mathrm{Mg}$ level (by $0.145 \mathrm{mmol} \mathrm{L}^{-1}$ ) in group II. The levels of $\mathrm{Ca}$ and $\mathrm{Fe}$ in group I significantly increased by $0.381 \mathrm{mmol} \mathrm{L}^{-1}$ and 16.024 umol L ${ }^{-1}$, respectively (Table 3).

We also compared the haematological parameters and plasma mineral content recorded before and after the wintering periods in 2016 and 2017. In the first year of the research, RBC and HCT significantly decreased by $1.031 \times 10^{12} \mathrm{~L}^{-1}$ and $2.239 \%(\mathrm{P}<0.05)$, respectively, after the winter period. In group I, a higher level of only $\mathrm{Cu}$ (by 5.168 umol $\mathrm{L}^{-1}$ ) was observed. With the exception of $\mathrm{Zn}$, the plasma concentrations of all minerals increased significantly in group II. There was an increase in the level of P from 2.448 to 
$2.812 \mathrm{mmol} \mathrm{L}^{-1}, \mathrm{Mg}$ from 0.682 to $0.880 \mathrm{mmol} \mathrm{L}^{-1}, \mathrm{Cu}$ from 12.438 to $16.437 \mathrm{umol} \mathrm{L}^{-1}$, Ca from 2.301 to $2.596 \mathrm{mmol} \mathrm{L}^{-1}$, and Fe from 32.386 to $36.106 \mathrm{umol} \mathrm{L}^{-1}(\mathrm{P}<0.05)$. A significant increase in the control group was only noted in the case of $\mathrm{P}, \mathrm{Mg}$, and $\mathrm{Cu}$. The content of $\mathrm{P}$ increased from 1.988 to $2.442 \mathrm{mmol} \mathrm{L}^{-1}, \mathrm{Mg}$ from 0.641 to $0.747 \mathrm{mmol} \mathrm{L}^{-1}$, and $\mathrm{Cu}$ from 12.277 to $15.754 \mu \mathrm{mol} \mathrm{L}^{-1}(\mathrm{P}<0.05)$ (Table 4).

In the second year of the investigations, there was a significant decrease (by $0.61 \times$ $10^{9} \mathrm{~L}^{-1}$ ) in $\mathrm{WBC}$ in the control group (III) after the winter period, whereas RBC and HGB significantly increased by $0.896 \times 10^{12} \mathrm{~L}^{-1}$ and $1.200 \mathrm{~g} \mathrm{~L}^{-1}$, respectively, $(P<0.05)$. The plasma $\mathrm{Zn}$ and $\mathrm{P}$ concentration in group I decreased after the winter period from 49.979 to $29.697 \mathrm{umol} \mathrm{L} \mathrm{u}^{-1}$ and from 2.802 to $1.629 \mathrm{mmol} \mathrm{L}^{-1}$, respectively $(P<0.05)$. In turn, the $\mathrm{Mg}$ and $\mathrm{Cu}$ content increased from 0.675 to $0.766 \mathrm{mmol} \mathrm{L}^{-1}$ and from 11.867 to $15.063 \mathrm{umol} \mathrm{L}^{-1}$, respectively $(P<0.05)$. In the other groups (II and III), the content of $\mathrm{Ca}$ declined statistically significantly after the winter period, i.e. by $0.349 \mathrm{mmol} \mathrm{L}^{-1}$ (Table 5).

Additionally, the antler and body weight was compared in the study groups. In all groups, the weight of the animals' antlers increased significantly between 2016 and 2107. The increase was substantially higher in group I (from 941.176 to $1558.235 \mathrm{~g}$ ) and III (from 1064.706 to $1450.588 \mathrm{~g}$ ) than in group II (from 1062.437 to $1185.000 \mathrm{~g})(P<0.05$ ). The body weight of the fallow deer before and after the winter period significantly increased in all groups as well (Table 6). Furthermore, the cycle of antler growth, velvet loss, and antler shedding was accelerated by on average 3 weeks in group II.

The changes in the haematological parameters and plasma mineral content in the farmed fallow deer were analysed statistically. A statistically significant difference was found in the magnitude of the change in the $\mathrm{Zn}$ level between the groups analysed in the pre-wintering period in the first and second year of the study $(F=11.653, P=0.003)$. Statistically significant differences were found between groups I and II (a mean increase by 30.559 umol L-1 in group I and by 12.609 umol L $^{-1}$ in group II) and between groups I and III (a mean increase by $12.609 \mathrm{umol} \mathrm{L}^{-1}$ in group I and by $14.185 \mathrm{umol} \mathrm{L}^{-1}$ in group III) (Table 7).

There was a statistically significant difference in the magnitude of the change in the $\mathrm{Ca}$ content between the analysed groups $(H=8.343, P=0.015)$ before the wintering period in 2016 and 2017. Statistically significant differences were found for groups I and II (a mean increase by $0.260 \mathrm{mmol} \mathrm{L}^{-1}$ in group I and by $0.661 \mathrm{mmol} \mathrm{L}^{-1}$ in group II) and between groups I and III (a mean increase by $0.260 \mathrm{mmol} \mathrm{L}^{-1}$ in group I and by $0.684 \mathrm{mmol} \mathrm{L}^{-1}$ in group III) (Table 7).

After the wintering period in the first and second year of the study, there was a statistically significant difference in the magnitude of the change in the levels of $\mathrm{Mg}$ $(F=5.001, P=0.013)$ and $\mathrm{Ca}(F=4.041, P=0.027)$ between the analysed groups. Statistically significant differences were found between groups I and II. On average, the $\mathrm{Mg}$ content increased by $0.114 \mathrm{mmol} \mathrm{L}^{-1}$ in group I and declined by $0.144 \mathrm{mmol} \mathrm{L}^{-1}$ in group II. Similarly, the content of Ca increased on average by $0.382 \mathrm{mmol} \mathrm{L}^{-1}$ in group I and decreased by $0.143 \mathrm{mmol} \mathrm{L}^{-1}$ in group II (Table 7). There was a statistically significant difference in the magnitude of the changes in the antler weight between the analysed groups $(H=18.544, P=0.0001)$. Statistically significant differences were found between groups I and II (a mean increase in the weight by $617.059 \mathrm{~g}$ in group I and by $122.563 \mathrm{~g}$ in group II) (Table 7).

Statistically significant differences were also found between the measurement terms in the study years. Before and after the wintering periods in 2016, there were 
differences in the magnitude of changes in the levels of $\mathrm{Ca}(F=4.464, P=0.017)$ and Fe $(F=3.727, P=0.032)$. Statistically significant differences were noted between groups I and II. On average, the Ca content decreased by Ca o $0.144 \mathrm{mmol} \mathrm{L}^{-1}$ in group $\mathrm{I}$ and increased by $0.296 \mathrm{mmol} \mathrm{L}^{-1}$ in group II. Similarly, the Fa content increased on average by 2.989 umol L $\mathrm{L}^{-1}$ in group I and increased by $3.720 \mathrm{umol} \mathrm{L}^{-1}$ in group II (Table 8). Before and after the wintering period in 2017, there were significant differences in the magnitude of the changes in the $\mathrm{Zn}$ content only $(F=4.199$, $P=0.024)$. Statistically significant differences were found between groups I and III. On average, the $\mathrm{Zn}$ content decreased by $20.283 \mathrm{umol} \mathrm{L}^{-1}$ in group I and decrease by 0.998 umol L $\mathrm{L}^{-1}$ in group III (Table 8).

The research also analyzed the effect of out-object (natural and artificial light length and $10 \%$ and $16 \%$ protein in the diet) and intra-object (change of results over time). No statistically significant effect of time as well as the effect of protein alone and light on WBC was observed. However, a significant effect of time and protein interaction was noted $\left(F(3,60)=3.864, P=0.038\right.$, eta $\left.{ }^{2}=0.162\right)$ and the effect of time and light interaction $\left(F(3,60)=4.089, P=0.032\right.$, eta $\left.{ }^{2}=0.170\right)($ Table 9).

In the case of $\mathrm{RBC}$, only the effect of time $(F(3,60)=26.913, P<0.001$, eta $\left.a^{2}=0.574\right)$ was significant, the difference was between the measurements from 2016 and 2017: 1 - 3, 1 - 4, 2-3,2 - 4 (Table 9).

No significant effect of time, protein and light, and interaction between them on HGB and HCT was observed (Table 9).

In the case of $\mathrm{Zn}$, a significant effect of time alone was demonstrated ( $F$ (3, $60)=32.972, P<0.001$, eta $\left.{ }^{2}=0.507\right)$, the significant difference was met between the measurements from 2016 and 2017: 1 - 3, 1 - 4, 2-3,2 - 4. A significant effect of time and protein interaction $\left(F(3,60)=5.374, P=0.008\right.$, eta $\left.^{2}=0.144\right)$ and time and light interaction $\left(F(3,60)=4.793, P=0.013\right.$, eta $\left.{ }^{2}=0.013\right)$ were also met for $\mathrm{Zn}$ concentration in fallow deer plasma. However, the time effect itself was the strongest $\left(\right.$ eta $\left.{ }^{2}=0.507\right)($ Table 9).

No significant effect of time, protein and light as well as the relationship between them on the P plasma concentration of animals was observed (Table 9).

The plasma Mg content was influenced by the time effect $(F(3,60)=5.625$, $P=0.001$, $e t a^{2}=0.149$ ), a difference was dependent between measurements from 2016 and 2016 and 2017: $1-2,1-3,1-4$. A significant effect of time and light was also shown $\left(F(3,60)=2.816, P=0.043\right.$, eta $\left.{ }^{2}=0.081\right)$. The time effect was stronger $\left(e t a^{2}=0.149\right)($ Table 9).

The plasma $\mathrm{Cu}$ content was affected only by the time effect $(F(3,60)=5.551$, $\left.P=0.005, \quad e t a^{2}=0.148\right), \quad$ a statistically significant difference was between measurements 1 - 2, 1 - 4 (Table 9).

In the case of $\mathrm{Ca}$, a significant effect of time alone was demonstrated ( $F$ (3, $60)=20.736, P<0.001$, eta $^{2}=0.393$ ), the significant difference was between the measurements from 2016 and 2017 and from 2017 alone: 1 - 3, 1 - 4, 2 - 3, 3 - 4. In addition, a significant effect of time and light interaction $(F(3,60)=4.923$, $P=0.003$, $e t a^{2}=0.133$ ) on the fallow deer plasma Ca content was also demonstrated. The time effect itself was again stronger in this case (Table 9).

Demonstrated a significant effect of time alone on plasma Fe concentration $(F(3$, $60)=12.506, P<0.001$, $\left.e t a^{2}=0.281\right)$, a significant difference was between the measurements: 1 - 3, 1-4, 2-3, 2- 4 (Table 9). 
Table 2. Comparison of some haematological parameters and mineral concentration in the plasma of farmed fallow deer before the winter period in 2016 and 2017

\begin{tabular}{|c|c|c|c|c|c|c|c|c|c|c|c|c|c|c|c|c|c|c|}
\hline \multirow{3}{*}{$\begin{array}{l}\text { Analyzed } \\
\text { variable }\end{array}$} & \multicolumn{6}{|c|}{ Group I } & \multicolumn{6}{|c|}{ Group II } & \multicolumn{6}{|c|}{ Group III } \\
\hline & \multicolumn{2}{|c|}{$\begin{array}{c}\text { Before } \\
\text { wintering 2016 }\end{array}$} & \multicolumn{2}{|c|}{\begin{tabular}{|c|} 
Before wintering \\
2017 \\
\end{tabular}} & \multicolumn{2}{|c|}{ 2016-2017 } & \multicolumn{2}{|c|}{\begin{tabular}{|c|} 
Before \\
wintering 2016
\end{tabular}} & \multicolumn{2}{|c|}{$\begin{array}{c}\text { Before wintering } \\
2017\end{array}$} & \multicolumn{2}{|c|}{ 2016-2017 } & \multicolumn{2}{|c|}{$\begin{array}{c}\text { Before } \\
\text { wintering } 2016\end{array}$} & \multicolumn{2}{|c|}{\begin{tabular}{|c|} 
Before wintering \\
2017
\end{tabular}} & \multicolumn{2}{|c|}{ 2016-2017 } \\
\hline & $\mathbf{M}$ & SD & $\mathbf{M}$ & SD & $\mathbf{t}^{\mathbf{a} / \mathbf{Z}^{\mathbf{b}}}$ & $P$ & $\mathbf{M}$ & SD & $\mathbf{M}$ & SD & $\mathbf{t}^{\mathrm{a} / \mathbf{Z}^{\mathrm{b}}}$ & $P$ & $\mathbf{M}$ & SD & $\mathbf{M}$ & SD & $\mathbf{t}^{\mathrm{a} / \mathbf{Z}^{\mathrm{b}}}$ & $P$ \\
\hline \multicolumn{19}{|c|}{ Haematological parameters } \\
\hline $\begin{array}{c}\text { WBC } \\
\left(10^{9} \mathrm{~L}^{-1}\right)\end{array}$ & 5.288 & 2.772 & 3.638 & 0.753 & $2.039^{\mathrm{b}}$ & $0.041^{*}$ & 3.380 & 1.010 & 3.874 & 0.607 & $-1.308^{\mathrm{a}}$ & 0.232 & 3.807 & 0.625 & 4.442 & 0.876 & $-2.145^{\mathrm{a}}$ & 0.085 \\
\hline $\begin{array}{c}\mathrm{RBC}\left(10^{12}\right. \\
\left.\mathrm{L}^{-1}\right)\end{array}$ & 15.008 & 0.878 & 11.916 & 0.826 & $14.909^{\mathrm{a}}$ & $<0.005^{*}$ & 14.050 & 0.872 & 11.140 & 1.348 & $8.429^{\mathrm{a}}$ & $<0.005^{*}$ & 14.133 & 1.015 & 11.637 & 1.127 & $10.485^{\mathrm{a}}$ & $<0.005^{*}$ \\
\hline $\begin{array}{l}\mathrm{HGB} \\
\left(\mathrm{g} \mathrm{L}^{-1}\right)\end{array}$ & 17.700 & 0.773 & 17.658 & 0.867 & $0.275^{\mathrm{b}}$ & 0.784 & 17.887 & 0.356 & 16.925 & 1.801 & $1.581^{\mathrm{a}}$ & 0.158 & 17.850 & 0.493 & 17.450 & 1.508 & $0.737^{\mathrm{a}}$ & 0.494 \\
\hline $\begin{array}{c}\mathrm{HCT} \\
(\%)\end{array}$ & 49.750 & 2.385 & 48.500 & 2.938 & $1.077^{\mathrm{a}}$ & 0.304 & 50.275 & 2.111 & 47.650 & 5.261 & $1.451^{\mathrm{a}}$ & 0.190 & 48.633 & 1.311 & 48.400 & 5.230 & $0.123^{\mathrm{a}}$ & 0.907 \\
\hline \multicolumn{19}{|c|}{ Content of minerals in plasma } \\
\hline $\begin{array}{c}\mathrm{Zn} \\
\left(\mathrm{umol} \mathrm{L}{ }^{-1}\right) \\
\end{array}$ & 19.420 & 2.811 & 49.979 & 11.053 & $3.059^{\mathrm{b}}$ & $0.002 *$ & 22.237 & 4.501 & 34.846 & 11.800 & $-3.534^{a}$ & $0.004 *$ & 22.258 & 4.510 & 36.442 & 10.661 & $-3.949^{a}$ & $0.002 *$ \\
\hline $\begin{array}{c}\mathrm{P} \\
\left(\mathrm{mmol} \mathrm{L}^{-1}\right)\end{array}$ & 2.535 & 0.338 & 2.802 & 3.154 & $2.118^{\mathrm{b}}$ & $0.034^{*}$ & 2.507 & 0.424 & 2.165 & 0.529 & $1.707^{\mathrm{a}}$ & 0.116 & 1.864 & 0.852 & 5.631 & 11.956 & $0.978^{\mathrm{b}}$ & 0.328 \\
\hline $\begin{array}{c}\mathrm{Mg} \\
\left(\mathrm{mmol} \mathrm{L}^{-1}\right) \\
\end{array}$ & 0.594 & 0.225 & 0.675 & 0.064 & $-1.101^{\mathrm{a}}$ & 0.294 & 0.680 & 0.063 & 0.854 & 0.206 & $2.432^{\mathrm{b}}$ & $0.015^{*}$ & 0.647 & 0.094 & 0.787 & 0.262 & $1.529^{\mathrm{b}}$ & 0.126 \\
\hline $\begin{array}{c}\mathrm{Cu} \\
\left(\mathrm{umol} \mathrm{L}{ }^{-1}\right)\end{array}$ & 11.231 & 1.762 & 11.867 & 3.439 & $0.314^{\mathrm{b}}$ & 0.754 & 12.269 & 2.516 & 13.991 & 2.629 & $-1.860^{\mathrm{a}}$ & 0.089 & 12.344 & 2.508 & 13.352 & 3.862 & $-0.925^{\mathrm{a}}$ & 0.375 \\
\hline $\begin{array}{c}\mathrm{Ca} \\
\left(\mathrm{mmol} \mathrm{L}^{-1}\right)\end{array}$ & 2.576 & 0.218 & 2.836 & 0.425 & $2.628^{\mathrm{b}}$ & $0.008 *$ & 2.234 & 0.134 & 2.895 & 0.326 & $-6.805^{a}$ & $<0.005^{*}$ & 2.213 & 0.250 & 2.898 & 0.411 & $-5.090^{\mathrm{a}}$ & $<0.005^{*}$ \\
\hline $\begin{array}{c}\mathrm{Fe} \\
\left(\mathrm{umol} \mathrm{L} \mathrm{L}^{-1}\right)\end{array}$ & 31.903 & 3.522 & 38.552 & 7.983 & $-2.672^{b}$ & $0.0217^{*}$ & 32.835 & 4.274 & 45.881 & 12.144 & $-3.619^{a}$ & $0.004 *$ & 29.863 & 5.638 & 36.689 & 6.201 & $-3.523^{\mathrm{a}}$ & $0.004 *$ \\
\hline
\end{tabular}

$\mathrm{a}$ - the Student's $t$-test result, b - Mann-Whitney test results, M-mean, SD- standard deviation, *values statistically significant $P<0.05$ 
Table 3. Comparison of some haematological parameters and mineral concentration in the plasma of farmed fallow deer after the winter period in 2016 and 2017

\begin{tabular}{|c|c|c|c|c|c|c|c|c|c|c|c|c|c|c|c|c|c|c|}
\hline \multirow{3}{*}{$\begin{array}{c}\text { Analyzed } \\
\text { variable }\end{array}$} & \multicolumn{6}{|c|}{ Group I } & \multicolumn{6}{|c|}{ Group II } & \multicolumn{6}{|c|}{ Group III } \\
\hline & \multicolumn{2}{|c|}{\begin{tabular}{|} 
After wintering \\
2016
\end{tabular}} & \multicolumn{2}{|c|}{$\begin{array}{c}\text { After wintering } \\
2017\end{array}$} & \multicolumn{2}{|c|}{ 2016-2017 } & \multicolumn{2}{|c|}{\begin{tabular}{|c} 
After wintering \\
2016
\end{tabular}} & \multicolumn{2}{|c|}{\begin{tabular}{|c|} 
After wintering \\
2017
\end{tabular}} & \multicolumn{2}{|c|}{ 2016-2017 } & \multicolumn{2}{|c|}{$\begin{array}{c}\text { After wintering } \\
2016\end{array}$} & \multicolumn{2}{|c|}{\begin{tabular}{|c|} 
After wintering \\
2017
\end{tabular}} & \multicolumn{2}{|c|}{ 2016-2017 } \\
\hline & $\mathbf{M}$ & SD & $\mathbf{M}$ & SD & $\mathbf{t}^{\mathrm{a}} / \mathbf{Z}^{\mathrm{b}}$ & $P$ & $\mathbf{M}$ & SD & $\mathbf{M}$ & SD & $\mathbf{t}^{\mathrm{a} / \mathbf{Z}^{\mathrm{b}}}$ & $\boldsymbol{P}$ & $\mathbf{M}$ & SD & $\mathbf{M}$ & SD & $\mathbf{t}^{\mathrm{a}} / \mathbf{Z}^{\mathrm{b}}$ & $P$ \\
\hline \multicolumn{19}{|c|}{ Haematological parameters } \\
\hline $\begin{array}{c}\text { WBC } \\
\left(10^{9} \mathrm{~L}^{-1}\right)\end{array}$ & 3.868 & 0.769 & 3.912 & 0.781 & $-0.176^{a}$ & 0.864 & 4.053 & 0.918 & 3.761 & 0.816 & $0.917^{\mathrm{a}}$ & 0.379 & 3.904 & 0.885 & 4.561 & 0.733 & $-2.211^{\mathrm{a}}$ & $0.049 *$ \\
\hline $\begin{array}{c}\mathrm{RBC} \\
\left(10^{12} \mathrm{~L}^{-1}\right)\end{array}$ & 14.140 & 0.899 & 12.375 & 0.242 & $6.144^{\mathrm{a}}$ & $\mid \begin{array}{c}<0.005 \\
*\end{array}$ & 14.675 & 3.135 & 12.060 & 0.559 & $2.667^{\mathrm{b}}$ & $0.007 *$ & 15.042 & 2.059 & 12.209 & 0.496 & $3.059^{\mathrm{b}}$ & $0.002 *$ \\
\hline $\begin{array}{l}\mathrm{HGB} \\
\left(\mathrm{g} \mathrm{L}^{-1}\right)\end{array}$ & 17.640 & 1.265 & 18.300 & 0.558 & $-2.199^{a}$ & 0.055 & 18.425 & 1.835 & 18.067 & 0.943 & $0.039^{\mathrm{b}}$ & 0.969 & 18.300 & 1.467 & 18.192 & 0.640 & $0.470^{\mathrm{b}}$ & 0.638 \\
\hline $\begin{array}{c}\mathrm{HCT} \\
(\%)\end{array}$ & 47.860 & 3.739 & 47.740 & 2.737 & $0.127^{\mathrm{a}}$ & 0.902 & 49.333 & 8.564 & 47.200 & 2.676 & $0.789^{\mathrm{a}}$ & 0.446 & 50.975 & 6.039 & 47.133 & 2.319 & $1.647^{\mathrm{b}}$ & 0.099 \\
\hline \multicolumn{19}{|c|}{ Content of minerals in plasma } \\
\hline $\begin{array}{c}\mathrm{Zn} \\
\left(\mathrm{umol} \mathrm{L}{ }^{-1}\right)\end{array}$ & 19.455 & 3.286 & 28.737 & 11.581 & $-3116^{a}$ & $0.008 *$ & 21.614 & 2.725 & 32.013 & 16.466 & $-1.914^{\mathrm{a}}$ & 0.085 & 18.475 & 4.549 & 35.445 & 11.924 & $-4.674^{\mathrm{a}}$ & $\begin{array}{c}<0.005 \\
*\end{array}$ \\
\hline $\begin{array}{c}\mathrm{P} \\
(\mathrm{mmol} \mathrm{L} \\
-1)\end{array}$ & 2.603 & 0.520 & 1.609 & 0.558 & $4.652^{\mathrm{a}}$ & $\begin{array}{c}<0.005 \\
*\end{array}$ & 2.834 & 0.296 & 1.777 & 0.369 & $9.862^{\mathrm{a}}$ & $\begin{array}{c}<0.005 \\
*\end{array}$ & 2.400 & 0.328 & 1.821 & 0.355 & $3.760^{\mathrm{a}}$ & $0.003 *$ \\
\hline $\begin{array}{c}\mathrm{Mg} \\
(\mathrm{mmol} \mathrm{L}-1)\end{array}$ & 0.656 & 0.168 & 0.770 & 0.111 & $-1.814^{\mathrm{a}}$ & 0.094 & 0.885 & 0.099 & 0.740 & 0.160 & $2.856^{\mathrm{a}}$ & $0.017 *$ & 0.735 & 0.139 & 0.746 & 0.125 & $-0.192^{\mathrm{a}}$ & 0.852 \\
\hline $\begin{array}{c}\mathrm{Cu} \\
\left(\mathrm{umol} \mathrm{L}^{-1}\right)\end{array}$ & 16.888 & 8.093 & 14.718 & 4.032 & $0.834^{\mathrm{a}}$ & 0.420 & 16.273 & 1.563 & 15.318 & 7.690 & $0.403^{\mathrm{a}}$ & 0.695 & 15.305 & 3.712 & 16.192 & 7.361 & $-0.356^{a}$ & 0.729 \\
\hline $\begin{array}{c}\mathrm{Ca} \\
\left(\mathrm{mmol} \mathrm{L} \mathrm{L}^{-1}\right)\end{array}$ & 2.391 & 0.344 & 2.772 & 0.441 & $-3.562^{a}$ & 0.0048 & 2.616 & 0.242 & 2.474 & 0.443 & $0.809^{\mathrm{a}}$ & 0.437 & 2.415 & 0.378 & 2.625 & 0.239 & $-1.889^{a}$ & 0.085 \\
\hline $\begin{array}{c}\mathrm{Fe} \\
(\text { umol L-1) }\end{array}$ & 29.747 & 4.733 & 45.773 & 13.085 & $-4.819^{\mathrm{a}}$ & $\begin{array}{c}<0.005 \\
*\end{array}$ & 37.888 & 4.956 & 54.575 & 32.823 & $-1.671^{\mathrm{a}}$ & 0.125 & 31.997 & 7.776 & 46.989 & 25.171 & $-1.900^{\mathrm{a}}$ & 0.083 \\
\hline
\end{tabular}

$\mathrm{a}$ - the Student's $t$-test result, b - Mann-Whitney test results, M-mean, SD- standard deviation, *values statistically significant $P<0.05$ 
Table 4. Comparison of some haematological parameters and mineral concentration in the plasma of farmed fallow deer before and after the winter period in 2016

\begin{tabular}{|c|c|c|c|c|c|c|c|c|c|c|c|c|c|c|c|c|c|c|}
\hline \multirow{3}{*}{$\begin{array}{l}\text { Analyzed } \\
\text { variable }\end{array}$} & \multicolumn{6}{|c|}{ Group I } & \multicolumn{6}{|c|}{ Group II } & \multicolumn{6}{|c|}{ Group III } \\
\hline & \multicolumn{2}{|c|}{$\begin{array}{c}\text { Before wintering } \\
2016\end{array}$} & \multicolumn{2}{|c|}{$\begin{array}{c}\text { After wintering } \\
2016\end{array}$} & \multicolumn{2}{|c|}{ Before-after } & \multicolumn{2}{|c|}{$\begin{array}{c}\text { Before wintering } \\
2016\end{array}$} & \multicolumn{2}{|c|}{\begin{tabular}{|c|} 
After wintering \\
2016
\end{tabular}} & \multicolumn{2}{|c|}{ Before-after } & \multicolumn{2}{|c|}{$\begin{array}{c}\text { Before wintering } \\
2016\end{array}$} & \multicolumn{2}{|c|}{\begin{tabular}{|c|} 
After wintering \\
2016
\end{tabular}} & \multicolumn{2}{|c|}{ Before-after } \\
\hline & $\mathbf{M}$ & SD & $\mathbf{M}$ & SD & $\mathbf{t}^{\mathrm{a} / \mathbf{Z}^{\mathrm{b}}}$ & $P$ & $\mathbf{M}$ & SD & M & SD & $\mathbf{t}^{\mathrm{a} / \mathbf{Z}^{\mathrm{b}}}$ & $P$ & M & SD & $\mathbf{M}$ & SD & $\mathbf{t}^{\mathbf{a} / \mathbf{Z}^{\mathbf{b}}}$ & $P$ \\
\hline \multicolumn{19}{|c|}{ Haematological parameters } \\
\hline $\begin{array}{c}\text { WBC } \\
\left(10^{9} \mathrm{~L}^{-1}\right)\end{array}$ & 4.841 & 2.535 & 3.809 & 0.689 & $0.804^{\mathrm{b}}$ & 0.422 & 3.240 & 0.879 & 3.761 & 0.599 & $-1.707^{\mathrm{a}}$ & 0.119 & 3.564 & 0.775 & 3.764 & 0.898 & $-1.068^{\mathrm{a}}$ & 0.316 \\
\hline $\begin{array}{c}\mathrm{RBC} \\
\left(10^{12} \mathrm{~L}^{-1}\right)\end{array}$ & 15.054 & 0.855 & 14.023 & 0.891 & $3.640^{\mathrm{a}}$ & $\begin{array}{c}0.414 \\
*\end{array}$ & 14.218 & 0.785 & 14.518 & 2.749 & $0.000^{\mathrm{b}}$ & 1.000 & 14.322 & 0.960 & 15.789 & 2.996 & $0.533^{\mathrm{b}}$ & 0.594 \\
\hline $\begin{array}{l}\mathrm{HGB} \\
\left(\mathrm{g} \mathrm{L}^{-1}\right)\end{array}$ & 17.585 & 0.779 & 17.515 & 1.152 & $0.278^{\mathrm{a}}$ & 0.786 & 17.873 & 0.307 & 18.291 & 1.566 & $0.509^{\mathrm{b}}$ & 0.610 & 17.911 & 0.521 & 18.955 & 2.186 & $0.889^{\mathrm{b}}$ & 0.374 \\
\hline $\begin{array}{l}\mathrm{HCT} \\
(\%)\end{array}$ & 49.600 & 2.475 & 47.361 & 3.381 & $2.359^{\mathrm{a}}$ & $\begin{array}{c}0.036 \\
*\end{array}$ & 50.009 & 1.844 & 49.627 & 7.37 & $0.157^{\mathrm{a}}$ & 0.878 & 49.056 & 1.859 & 53.267 & 8.841 & $0.886^{\mathrm{b}}$ & 0.374 \\
\hline \multicolumn{19}{|c|}{ Content of minerals in plasma } \\
\hline $\begin{array}{c}\mathrm{Zn} \\
\left(\mathrm{umol} \mathrm{L}{ }^{-1}\right) \\
\end{array}$ & 19.680 & 2.720 & 18.348 & 3.655 & $1.126^{\mathrm{a}}$ & 0.277 & 27.563 & 4.257 & 21.707 & 3.822 & $-0.096^{\mathrm{a}}$ & 0.925 & 21.234 & 4.597 & 18.911 & 4.924 & $1.706^{\mathrm{b}}$ & 0.088 \\
\hline $\begin{array}{c}\mathrm{P} \\
\left(\mathrm{mmol} \mathrm{L}^{-1}\right)\end{array}$ & 2.471 & 0.365 & 2.496 & 0.528 & $-0.170^{\mathrm{a}}$ & 0.867 & 2.448 & 0.493 & 2.812 & 0.326 & $-2.475^{\mathrm{a}}$ & $0.026^{*}$ & 1.988 & 0.742 & 2.442 & 0.351 & $2.499^{\mathrm{b}}$ & $\begin{array}{c}0.012 \\
*\end{array}$ \\
\hline $\begin{array}{c}\mathrm{Mg} \\
\left(\mathrm{mmol} \mathrm{L}^{-1}\right)\end{array}$ & 0.569 & 0.228 & 0.636 & 0.168 & $-0.865^{\mathrm{a}}$ & 0.399 & 0.682 & 0.0567 & 0.880 & 0.106 & $-6.736^{a}$ & $\begin{array}{c}<0.00 \\
5^{*}\end{array}$ & 0.641 & 0.084 & 0.747 & 0.135 & $2.508^{b}$ & $\begin{array}{c}0.012 \\
*\end{array}$ \\
\hline $\begin{array}{c}\mathrm{Cu} \\
\left(\mathrm{umol} \mathrm{L} \mathrm{L}^{-1} \text { ) }\right.\end{array}$ & 10.884 & 1.780 & 16.052 & 7.694 & $-2.485^{b}$ & $\begin{array}{c}0.013 \\
*\end{array}$ & 12.438 & 2.282 & 16.437 & 2.287 & $-4.913^{\mathrm{a}}$ & \begin{tabular}{c|}
$<0.00$ \\
$5^{*}$ \\
\end{tabular} & 12.277 & 2.286 & 15.754 & 3.516 & $-3.459^{\mathrm{a}}$ & $\begin{array}{c}0.003 \\
*\end{array}$ \\
\hline $\begin{array}{c}\mathrm{Ca} \\
\left(\mathrm{mmol} \mathrm{L}^{-1}\right)\end{array}$ & 2.506 & 0.244 & 2.362 & 0.516 & $1.107^{\mathrm{a}}$ & 0.284 & 2.301 & 0.182 & 2.596 & 0.253 & $-3.339^{a}$ & $0.004 *$ & 2.222 & 0.236 & 2.406 & 0.364 & $-1.819^{\mathrm{a}}$ & 0.088 \\
\hline $\begin{array}{c}\mathrm{Fe} \\
(\text { umol L-1) }\end{array}$ & 31.691 & 3.716 & 28.701 & 4.848 & $1.902^{\mathrm{a}}$ & 0.075 & 32.386 & 4.412 & 36.106 & 5.837 & $-2.327^{\mathrm{a}}$ & $0.034 *$ & 29.413 & 5.785 & 32.178 & 8.324 & $-1.136^{a}$ & 0.274 \\
\hline
\end{tabular}

a - the Student's $t$-test result, $\mathrm{b}$ - Mann-Whitney test results, M-mean, SD- standard deviation, *values statistically significant $P<0.05$ 
Table 5. Comparison of some haematological parameters and mineral concentration in the plasma of farmed fallow deer before and after the winter period in 2017

\begin{tabular}{|c|c|c|c|c|c|c|c|c|c|c|c|c|c|c|c|c|c|c|}
\hline \multirow{3}{*}{$\begin{array}{l}\text { Analyzed } \\
\text { variable }\end{array}$} & \multicolumn{6}{|c|}{ Group I } & \multicolumn{6}{|c|}{ Group II } & \multicolumn{6}{|c|}{ Group III } \\
\hline & \multicolumn{2}{|c|}{$\begin{array}{c}\text { Before wintering } \\
2017\end{array}$} & \multicolumn{2}{|c|}{\begin{tabular}{|c|} 
After wintering \\
2017 \\
\end{tabular}} & \multicolumn{2}{|c|}{ Before-after } & \multicolumn{2}{|c|}{$\begin{array}{c}\text { Before wintering } \\
2017\end{array}$} & \multicolumn{2}{|c|}{$\begin{array}{c}\text { After wintering } \\
2017\end{array}$} & \multicolumn{2}{|c|}{ Before-after } & \multicolumn{2}{|c|}{\begin{tabular}{|c} 
Before wintering \\
2017
\end{tabular}} & \multicolumn{2}{|c|}{$\begin{array}{c}\text { After wintering } \\
2017\end{array}$} & \multicolumn{2}{|c|}{ Before-after } \\
\hline & $\mathbf{M}$ & SD & $\mathbf{M}$ & SD & $\mathbf{t}^{\mathbf{a}} / \mathbf{Z}^{\mathbf{b}}$ & $P$ & $\mathbf{M}$ & SD & $\mathbf{M}$ & SD & $\mathbf{t}^{\mathrm{a} / \mathbf{Z}^{\mathrm{b}}}$ & $P$ & $\mathbf{M}$ & SD & $\mathbf{M}$ & SD & $\mathbf{t}^{\mathrm{a} / \mathbf{Z}^{\mathrm{b}}}$ & $P$ \\
\hline \multicolumn{19}{|c|}{ Haematological parameters } \\
\hline $\begin{array}{c}\text { WBC } \\
\left(10^{9} \mathrm{~L}^{-1}\right)\end{array}$ & 3.638 & 0.753 & 4.042 & 0.745 & $-1.281^{\mathrm{a}}$ & 0.226 & 3.962 & 0.655 & 3.761 & 0.816 & $0.353 b$ & 0.724 & 3.951 & 0.917 & 4.561 & 0.733 & $-2.211^{\mathrm{a}}$ & $0.049 *$ \\
\hline $\begin{array}{c}\mathrm{RBC} \\
\left(10^{12} \mathrm{~L}^{-1}\right)\end{array}$ & 11.916 & 0.826 & 12.374 & 0.359 & $1.490^{\mathrm{b}}$ & 0.136 & 11.164 & 1.181 & 12.060 & 0.559 & $-3.442^{\mathrm{a}}$ & $0.005 *$ & 11.943 & 1.189 & 12.209 & 0.496 & $-1.103^{\mathrm{a}}$ & 0.293 \\
\hline $\begin{array}{l}\mathrm{HGB} \\
\left(\mathrm{g} \mathrm{L}^{-1}\right)\end{array}$ & 17.658 & 0.867 & 18.350 & 0.620 & $1.579^{\mathrm{b}}$ & 0.114 & 16.867 & 1.598 & 18.067 & 0.943 & $-3.035^{\mathrm{a}}$ & $0.011 *$ & 17.633 & 1.536 & 18.192 & 0.640 & $-1.582^{\mathrm{a}}$ & 0.142 \\
\hline $\begin{array}{c}\mathrm{HCT} \\
(\%)\end{array}$ & 48.500 & 2.938 & 48.050 & 2.800 & $0.549^{\mathrm{b}}$ & 0.583 & 47.391 & 4.631 & 47.200 & 2.675 & $0.177^{\mathrm{a}}$ & 0.862 & 49.058 & 4.744 & 47.133 & 2.329 & $1.858^{\mathrm{a}}$ & 0.090 \\
\hline \multicolumn{19}{|c|}{ Content of minerals in plasma } \\
\hline $\begin{array}{c}\mathrm{Zn} \\
\left(\mathrm{umol} \mathrm{L}{ }^{-1}\right) \\
\end{array}$ & 49.979 & 11.053 & 29.697 & 11.542 & $6.867^{\mathrm{a}}$ & $\begin{array}{c}<0.005 \\
*\end{array}$ & 35.599 & 12.069 & 32.013 & 16.467 & $0.522^{\mathrm{a}}$ & 0.613 & 36.442 & 10.661 & 35.444 & 11.924 & $0.191^{\mathrm{a}}$ & 0.852 \\
\hline $\begin{array}{c}\mathrm{P} \\
(\mathrm{mmol} \mathrm{L} \\
-1)\end{array}$ & 2.802 & 3.154 & 1.629 & 0.578 & $2.118^{\mathrm{b}}$ & $0.034 *$ & 2.128 & 0.539 & 1.777 & 0.369 & $2.094^{\mathrm{a}}$ & 0.063 & 5.631 & 11.956 & 1.812 & 0.371 & $1.689^{\mathrm{b}}$ & 0.091 \\
\hline $\begin{array}{c}\mathrm{Mg} \\
\left(\mathrm{mmol} \mathrm{L}^{-1}\right)\end{array}$ & 0.675 & 0.064 & 0.766 & 0.115 & $-2.547^{\mathrm{a}}$ & $0.027 *$ & 0.873 & 0.204 & 0.740 & 0.160 & $1.274^{b}$ & 0.202 & 0.786 & 0.262 & 0.746 & 0.124 & $0.157^{\mathrm{b}}$ & 0.875 \\
\hline $\begin{array}{c}\mathrm{Cu} \\
\left(\mathrm{umol} \mathrm{L}^{-1}\right)\end{array}$ & 11.867 & 3.439 & 15.063 & 4.008 & $-2.309^{a}$ & $0.041^{*}$ & 14.022 & 2.756 & 15.318 & 7.690 & $-0.493^{\mathrm{a}}$ & 0.632 & 13.352 & 3.862 & 16.192 & 7.361 & $-1.180^{\mathrm{a}}$ & 0.263 \\
\hline $\begin{array}{c}\mathrm{Ca} \\
\left(\mathrm{mmol} \mathrm{L}^{-1}\right)\end{array}$ & 2.836 & 0.425 & 2.811 & 0.437 & $0.156^{\mathrm{a}}$ & 0.879 & 2.899 & 0.341 & 2.473 & 0.443 & $3.104^{\mathrm{a}}$ & $0.011 *$ & 2.898 & 0.411 & 2.625 & 0.239 & $2.400^{\mathrm{a}}$ & $0.035^{*}$ \\
\hline $\begin{array}{c}\mathrm{Fe} \\
\left(\mathrm{umol} \mathrm{L}^{-1} \text { ) }\right.\end{array}$ & 38.552 & 7.983 & 47.158 & 12.632 & $-1.692^{\mathrm{a}}$ & 0.119 & 46.684 & 12.399 & 54.575 & 32.824 & $0.000^{\mathrm{b}}$ & 1.000 & 36.689 & 6.201 & 46.989 & 25.171 & $-1.349^{\mathrm{a}}$ & 0.204 \\
\hline
\end{tabular}

$\mathrm{a}$ - the Student's $t$-test result, $\mathrm{b}$ - Mann-Whitney test results, M-mean, SD- standard deviation, ${ }^{*}$ values statistically significant $P<0.05$ 
Table 6. Comparison of the antler and body weight before and after the winter period in 2016 and 2017 (calculations are given only for factors that were statistically significant)

\begin{tabular}{|c|c|c|c|c|c|c|c|c|c|c|c|c|c|c|c|c|c|}
\hline \multicolumn{6}{|c|}{ Group I } & \multicolumn{6}{|c|}{ Group II } & \multicolumn{6}{|c|}{ Group III } \\
\hline \multicolumn{2}{|c|}{2016} & \multicolumn{2}{|c|}{2017} & \multirow[b]{2}{*}{$\mathbf{t}^{\mathrm{a} / \mathbf{Z}^{\mathbf{b}}}$} & \multirow[b]{2}{*}{$P$} & \multicolumn{2}{|c|}{2016} & \multicolumn{2}{|c|}{2017} & \multirow[b]{2}{*}{$\mathbf{t}^{\mathbf{a}} / \mathbf{Z}^{\mathbf{b}}$} & \multirow[b]{2}{*}{$\boldsymbol{P}$} & \multicolumn{2}{|c|}{2016} & \multicolumn{2}{|c|}{2017} & \multirow[b]{2}{*}{$\mathbf{t}^{\mathrm{a}} / \mathbf{Z}^{\mathrm{b}}$} & \multirow[b]{2}{*}{$P$} \\
\hline $\mathbf{M}$ & SD & $\mathbf{M}$ & SD & & & $\mathbf{M}$ & SD & $\mathbf{M}$ & SD & & & $\mathbf{M}$ & SD & $\mathbf{M}$ & SD & & \\
\hline \multicolumn{18}{|c|}{ Weight of the antler (g) } \\
\hline 941.176 & 418.418 & 1558.235 & 300.317 & $3.621^{\mathrm{b}}$ & $<0.005^{*}$ & 1062.437 & 461.535 & 1185.000 & 327.088 & $-2.490^{\mathrm{a}}$ & $0.025 *$ & 1064.706 & 492.368 & 1450.588 & 506.439 & $-6.346^{\mathrm{a}}$ & $<0.005^{*}$ \\
\hline \multicolumn{18}{|c|}{ Body weight before wintering (October) (kg) } \\
\hline 72.588 & 11.847 & 79.824 & 9.105 & $-3.289^{\mathrm{a}}$ & $0.004 *$ & 70.125 & 6.459 & 78.250 & 6.618 & $-6.889^{\mathrm{a}}$ & $<0.005 *$ & 72.705 & 10.110 & 84.353 & 6.509 & $2.769^{\mathrm{b}}$ & $0.005 *$ \\
\hline \multicolumn{18}{|c|}{ Body weight after wintering (April/May) (kg) } \\
\hline 57.235 & 10.047 & 66.941 & 6.932 & $-8.349^{\mathrm{a}}$ & $<0.005 *$ & 59.500 & 10.857 & 69.125 & 5.488 & $3.181^{\mathrm{b}}$ & $0.001 *$ & 57.000 & 8.374 & 63.705 & 5.643 & $-6.638^{\mathrm{a}}$ & $<0.005^{*}$ \\
\hline
\end{tabular}

Table 7. Statistical analysis of the magnitude of changes in the haematological parameters, plasma mineral levels, and body and antler weight in the fallow deer before wintering period in 2016 and 2017 and after the winter periods in 2016 and 2017 (calculations are given only for factors that were statistically significant)

\begin{tabular}{|c|c|c|c|c|c|c|c|c|c|c|}
\hline \multirow{2}{*}{ Compare terms } & \multirow{2}{*}{$\begin{array}{c}\text { Analyzed } \\
\text { variable }\end{array}$} & \multicolumn{2}{|c|}{ Group I } & \multicolumn{2}{|c|}{ Group II } & \multicolumn{2}{|c|}{ Group III } & \multirow{2}{*}{$F^{\mathrm{a}} / H^{\mathrm{b}}$} & \multirow{2}{*}{$P$} & \multirow{2}{*}{$\begin{array}{l}\text { Intergroup } \\
\text { differences }\end{array}$} \\
\hline & & $\mathbf{M}$ & SD & $\mathbf{M}$ & SD & $\mathbf{M}$ & SD & & & \\
\hline \multirow{3}{*}{$\begin{array}{c}\text { Before wintering } \\
\text { 2016-2017 }\end{array}$} & \multicolumn{10}{|c|}{ Content of minerals in plasma } \\
\hline & $\begin{array}{c}\mathrm{Zn} \\
\left(\mathrm{umol} \mathrm{L}^{-1}\right)\end{array}$ & 30,559 & 10,787 & 12,609 & 12,360 & 14,185 & 12,441 & $11.653^{\mathrm{b}}$ & $0.003^{*}$ & I-II, I-III \\
\hline & $\begin{array}{c}\mathrm{Ca} \\
\left(\mathrm{mmol} \mathrm{L}^{-1}\right)\end{array}$ & 0,260 & 0,349 & 0,661 & 0,336 & 0,684 & 0,466 & $8.343^{\mathrm{b}}$ & $0.015^{*}$ & I-II, I-III \\
\hline \multirow{2}{*}{$\begin{array}{c}\text { After wintering } \\
2016-2017\end{array}$} & $\begin{array}{c}\mathrm{Mg} \\
\left(\mathrm{mmol} \mathrm{L}^{-1}\right)\end{array}$ & 0.114 & 0.226 & -0.144 & 0.168 & 0.011 & 0.196 & $5.001^{\mathrm{a}}$ & $0.013 *$ & I-II \\
\hline & $\begin{array}{c}\mathrm{Ca} \\
\left(\mathrm{mmol} \mathrm{L}^{-1}\right) \\
\end{array}$ & 0.382 & 0.387 & -0.143 & 0.585 & 0.209 & 0.385 & $4.041^{\mathrm{a}}$ & $0.027 *$ & I-II \\
\hline \multirow{2}{*}{$\begin{array}{c}\text { After wintering } \\
2016-2017\end{array}$} & \multicolumn{10}{|c|}{ Mass of antler and body weight } \\
\hline & mass of antler $(\mathrm{g})$ & 617.059 & 281.930 & 122.563 & 196.885 & 385.882 & 440.000 & $18.544^{\mathrm{c}}$ & $0.0001 *$ & I-II \\
\hline
\end{tabular}

a - ANOVA variance analysis, b - Kruskal-Wallis test, M-mean, SD- standard deviation, *values statistically significant $P<0.05$ 
Table 8. Statistical analysis of the magnitude of changes in the haematological parameters, plasma mineral levels in the fallow deer before and after the winter periods in 2016 and before and after the winter periods in 2017

\begin{tabular}{|c|c|c|c|c|c|c|c|c|c|c|}
\hline \multirow{2}{*}{ Compare terms } & \multirow{2}{*}{ Analyzed variable } & \multicolumn{2}{|c|}{ Group I } & \multicolumn{2}{|c|}{ Group II } & \multicolumn{2}{|c|}{ Group III } & \multirow{2}{*}{$F^{\mathrm{a}} / H^{\mathrm{b}}$} & \multirow{2}{*}{$P$} & \multirow{2}{*}{ Intergroup differences } \\
\hline & & $\mathbf{M}$ & SD & $\mathbf{M}$ & SD & $\mathbf{M}$ & SD & & & \\
\hline \multirow{3}{*}{ Before - after wintering 2016} & \multicolumn{10}{|c|}{ Content of minerals in plasma } \\
\hline & $\begin{array}{c}\mathrm{Ca} \\
\left(\mathrm{mmol} \mathrm{L}^{-1}\right)\end{array}$ & $-0,144$ & 0,537 & 0,296 & 0,354 & 0,184 & 0,404 & $4.464^{\mathrm{a}}$ & $0.017 *$ & I-II \\
\hline & $\begin{array}{c}\mathrm{Fe} \\
\text { (umol L-1) }\end{array}$ & $-2,989$ & 6,479 & 3,720 & 6,394 & 2,764 & 9,731 & $3.727^{\mathrm{a}}$ & $0.032 *$ & I-II \\
\hline Before - after wintering 2017 & $\begin{array}{c}\mathrm{Zn} \\
\left(\mathrm{umol} \mathrm{L} \mathrm{L}^{-1}\right)\end{array}$ & $-20,283$ & 10,231 & $-3,586$ & 22,799 & $-0,998$ & 18,051 & $4.199^{\mathrm{a}}$ & $0.024 *$ & I-III \\
\hline
\end{tabular}

a - ANOVA variance analysis, $\mathrm{b}$ - Kruskal-Wallis test, M-mean, SD- standard deviation, *values statistically significant $P<0.05$

Table 9. The effect of the influence of time, protein level in the diet, light day length and interaction between the analyzed variables on selected haematological parameters and the concentration of minerals in plasma of fallow deer (calculations are given only for factors that were statistically significant)

\begin{tabular}{|c|c|c|c|c|c|c|c|c|c|}
\hline & & & \multicolumn{4}{|c|}{ Estimated marginal averages } & \multirow{3}{*}{$F(3,60)$} & \multirow{3}{*}{$\boldsymbol{P}$} & \multirow{3}{*}{$e t a^{2}$} \\
\hline \multirow{2}{*}{\multicolumn{3}{|c|}{ Analyzed variables }} & $\begin{array}{l}\text { (1) Before } \\
\text { wintering }\end{array}$ & $\begin{array}{l}\text { (2) After } \\
\text { wintering }\end{array}$ & $\begin{array}{l}\text { (3) Before } \\
\text { wintering }\end{array}$ & $\begin{array}{l}\text { (4) After } \\
\text { wintering }\end{array}$ & & & \\
\hline & & & & & \multicolumn{2}{|c|}{2017} & & & \\
\hline \multicolumn{10}{|c|}{ Haematological parameters } \\
\hline \multirow{4}{*}{$\begin{array}{c}\text { WBC } \\
\left(10^{9} \mathrm{~L}^{-1}\right)\end{array}$} & \multirow{2}{*}{ Protein } & $10 \%$ & 3.333 & 3.833 & 4.000 & 4.000 & \multirow{2}{*}{3.864} & \multirow{2}{*}{$0.038 *$} & \multirow{2}{*}{0.162} \\
\hline & & $16 \%$ & 3.826 & 3.340 & 3.250 & 3.396 & & & \\
\hline & \multirow[b]{2}{*}{ Daylight } & Natural & 4.056 & 3.694 & 3.500 & 3.833 & \multirow[b]{2}{*}{4.089} & \multirow[b]{2}{*}{$0.032 *$} & \multirow[b]{2}{*}{0.17} \\
\hline & & $\begin{array}{l}\text { Artificial } \\
\text { elongated }\end{array}$ & 2.875 & 3.125 & 3.500 & 3.125 & & & \\
\hline
\end{tabular}




\begin{tabular}{|c|c|c|c|c|c|c|c|c|c|}
\hline $\begin{array}{c}\mathrm{RBC} \\
\left(10^{12} \mathrm{~L}^{-1}\right)\end{array}$ & & & 14.439 & 14.741 & 11.586 & 12.156 & 26.913 & $\begin{array}{c}<0.001 *, \text { Intergroup } \\
\text { differences: } \\
1-3,1-4,2-3,2-4\end{array}$ & 0.574 \\
\hline \multicolumn{10}{|c|}{ Content of minerals in plasma } \\
\hline \multirow{5}{*}{$\underset{(\mathrm{Zmol} \mathrm{L}}{\mathrm{Zn}}$} & \multicolumn{2}{|c|}{ Time } & 20.970 & 20.068 & 40.674 & 32.385 & 32.972 & $\begin{array}{c}<0.001^{*}, \text { Intergroup } \\
\text { differences: }\end{array}$ & 0.507 \\
\hline & \multirow{2}{*}{ Protein } & $10 \%$ & 22.257 & 18.476 & 36.442 & 35.445 & \multirow{2}{*}{5.374} & \multirow{2}{*}{$0.008^{*}$} & \multirow{2}{*}{0.144} \\
\hline & & $16 \%$ & 20.326 & 20.864 & 42.789 & 30.855 & & & \\
\hline & \multirow[b]{2}{*}{ Daylight } & Natural & 20.839 & 19.195 & 43.211 & 32.571 & \multirow[b]{2}{*}{4.793} & \multirow[b]{2}{*}{$0.013^{*}$} & \multirow[b]{2}{*}{0.130} \\
\hline & & $\begin{array}{l}\text { Artificial } \\
\text { elongated }\end{array}$ & 21.232 & 21.814 & 35.599 & 32.013 & & & \\
\hline \multirow{3}{*}{$\frac{\mathrm{Mg}}{\left(\mathrm{mmol} \mathrm{L}^{-1}\right)}$} & \multicolumn{2}{|c|}{ Time } & 0.637 & 0.761 & 0.778 & 0.751 & 5.625 & $\begin{array}{l}\text { 0.001, Intergroup } \\
\text { differences: } \\
1-2,1-3,1-4\end{array}$ & 0.149 \\
\hline & \multirow[b]{2}{*}{ Daylight } & Natural & 0.621 & 0.700 & 0.731 & 0.756 & \multirow[b]{2}{*}{2.816} & \multirow[b]{2}{*}{0.043} & \multirow[b]{2}{*}{0.081} \\
\hline & & $\begin{array}{l}\text { Artificial } \\
\text { elongated }\end{array}$ & 0.668 & 0.885 & 0.874 & 0.740 & & & \\
\hline$\underset{\left(\mathrm{Cu} o l L^{-1} \text { ) }\right.}{\mathrm{Cu}}$ & & & 11.754 & 16.309 & 13.080 & 15.524 & 5.551 & $\begin{array}{c}0.005^{*}, \text { Intergroup } \\
\text { differences: } \\
1-2,1-4\end{array}$ & 0.148 \\
\hline \multirow{3}{*}{$\begin{array}{c}\mathrm{Ca} \\
\left(\mathrm{mmol} \mathrm{L}^{-1}\right)\end{array}$} & \multicolumn{2}{|c|}{ Time } & 2.339 & 2.477 & 2.877 & 2.636 & 20.736 & $\begin{array}{c}<0.001 \text {, Intergroup } \\
\text { differences: } \\
1-3,1-4,2-3,3-4\end{array}$ & 0.393 \\
\hline & \multirow[b]{2}{*}{ Daylight } & Natural & 2.395 & 2.408 & 2.867 & 2.718 & \multirow[b]{2}{*}{4.923} & \multirow[b]{2}{*}{0.003} & \multirow[b]{2}{*}{0.133} \\
\hline & & $\begin{array}{c}\text { Artificial } \\
\text { elongated }\end{array}$ & 2.227 & 2.616 & 2.899 & 2.474 & & & \\
\hline $\begin{array}{c}\mathrm{Fe} \\
\left(\mathrm{umol} \mathrm{L} \mathrm{L}^{-1} \text { ) }\right.\end{array}$ & & & 31.495 & 33.359 & 40.641 & 49.574 & 12.506 & $\begin{array}{c}<0.001 * \text {, Intergroup } \\
\text { differences: } \\
1-3,1-4,2-3,2-4\end{array}$ & 0.281 \\
\hline
\end{tabular}

$F$ - ANOVA variance analysis, $P$ - statistically significant values, *correct epsilon Greenhouse-Geisser 


\section{Discussion}

There are only few studies on the effect of nutrition and altered day length on haematological parameters and plasma mineral concentrations in farmed fallow deer. Studies on various temperate cervid species conducted with the use of artificial manipulations of the daily photoperiod have shown that light has a significant impact on cervids (Jaczewski, 1954; French et al., 1960; Goss, 1969; Pollock, 1975; Simpson et al., 1983/84; Snyder et al., 1983).

Changing breeding conditions exert an effect on animal physiology, as evidenced by the results of the present study. The level of WBC in the farmed fallow deer usually had lower values in all groups (except for group I before the winter period in 2016 when the values were similar) than values reported in investigations of farmed deer (GasparLópez et al., 2011) in the respective months. It was shown in the fallow deer that the WBC count changed significantly in the control group, especially in 2017. This group was provided with the least favourable conditions, as reflected in the elevated plasma WBC levels. In the other research groups, the WBC count did not change significantly after the wintering period, as shown by Landete-Castillejos et al. (2002) or LandeteCastillejos et al. (2007), although that was the beginning of the antler development period. Another factor contributing to the slight reduction of WBC and the increase in $\mathrm{RBC}$ can be ascribed to the diet, as shown in the present study and investigations reported by Tomkins et al. (1991). The level of leukocytes varies seasonally and may constitute an adaptation to anticipated immune challenges by variation of the use of day length by animals (Nelson, 2004). Unfortunately, the present investigations do not confirm this finding. The RBC level in the farmed fallow deer was usually higher (especially in 2016); it was similar to the values noted in April by Gaspar-López et al. (2011) only after the winter period in 2017. Similarly, the HGB level was higher in the farmed fallow deer than those reported in investigations of farmed deer (Gaspar-López et al., 2011). HCT was higher in the farmed fallow deer, with the exception of group I, in which the value was similar to that reported by Gaspar-López et al. (2011) only after the winter period. The investigations conducted by Gaspar-López et al. (2011) demonstrated characteristic fluctuations in the RCB, HGB and HCT levels, which were substantially lower in November-December than in March-April. As suggested by DelGiudice et al. (1992), changes in nutrition may be a cause of seasonal fluctuations, which could explain the differences related to the altered light conditions in the present study. However, Gaspar-López et al. (2011) suggested another cause of these changes. The high testosterone level during the mating period (Gaspar-López et al., 2010) may be associated with high levels of the haematological parameters described in this study. Available literature provides evidence for stimulation of erythropoiesis by androgens (Gordon et al., 1970). Contrasting data were presented by Bubenik (2006), who suggested that antlers grow during a period of low concentrations of reproductive hormones. Interestingly, the RCB and HGB levels in the present study increased under the impact of the altered light conditions in the second year of the study, which may confirm stimulation of the erythropoiesis process probably by the increased estradiol content during this time. The investigations conducted by Bubenik et al. (1979) demonstrate an increase in the concentration of this hormone in spring and autumn in male white-tailed deer (Odocoileus virginianus). Estradiol blocks of the activity of testes and its high levels in spring prevent premature stimulation of spermatogenesis in 
a period that is unsuitable for deer reproduction. This was confirmed by Bubenik et al. (2005) by analysis of blood collected from growing antlers and velvet, where this hormone was present in high concentrations.

The plasma concentration of $\mathrm{Ca}, \mathrm{P}$, and $\mathrm{Mg}$ in the farmed fallow deer in the analysed months was higher than or similar to the values reported by Kuba (2014). In the present study, the animal group exposed to the altered day length regime exhibited a significant increase in the plasma concentration of most minerals $(\mathrm{P}, \mathrm{Mg}, \mathrm{Cu}, \mathrm{Ca}, \mathrm{Fe})$ after the winter period in 2016, which indicates accelerated development of antlers in the farmed fallow deer. Only the $\mathrm{Cu}$ content increased in group I and higher $\mathrm{Mg}$ and $\mathrm{Cu}$ levels were observed in group III. However, as early as in 2017, such an intensive increase in the mineral content (except for $\mathrm{Ca}$ ) was not noted in the plasma of the group exposed to the greater day length. This was probably associated with the proper and constant level of nutrition, which prevented changes in the blood mineral concentration despite the period of antler growth (Gaspar-López et al., 2011). Interestingly, group I only, which was supplemented with a higher amount of protein in the diet, exhibited lower $\mathrm{Zn}$ and $\mathrm{P}$ content and a higher $\mathrm{Mg}$ and $\mathrm{Cu}$ level in the plasma after the winter period in 2017.

Additionally, high $\mathrm{Zn}$ concentrations in the plasma of the farmed fallow deer were observed before the winter period in all groups in 2017. This was probably related to the fact that the animals were subjected to the experimental conditions a month earlier than in 2016. $\mathrm{Zn}$ is responsible for the normal testosterone concentration and proper function of the immune system (Bartoskewitz et al., 2007). After antler growth and mating periods, the immune system of cervids can return to homeostasis, hence the increased uptake of this mineral in the blood (Kun et al., 2015). This may also be a result of supplementation, as shown by Suresh et al. (2013).

The concentration of $\mathrm{P}$ and $\mathrm{Mg}$ in the plasma of the farmed fallow deer was in the range reported by Kučer et al. (2013). The $\mathrm{Cu}$ content in the fallow deer plasma significantly increased after the winter period in all groups in 2016 and only in group I in 2017. This indicates a high demand for $\mathrm{Cu}$ after the pasture period as well as a need for adequate supplementation and the necessity to provide the animals with appropriate conditions in winter to compensate for nutritional deficiencies caused by the decline in the nutritional value of pastures in late autumn (Padilla et al., 2000; Bao et al., 2010).

The fallow deer body weight in the pre-wintering period was evidently higher than after the winter, which was reported in investigations of other cervid species as well. Increased liveweight gain during summer in comparison to winter has been recorded in all arctic, boreal and temperate deer so far studied (McEwan, 1968; Bandy et al., 1970; Pollock, 1975; Asher, 1993). The deer voluntarily reduce their appetite during winter (McEwan, 1968). The cycle of voluntary food intake and growth are known to be under photoperiodic control (Suttie and Simpson, 1985). Whereas for reproductive seasonality the short days of autumn are thought to provide a stimulatory cue for reproduction in temperate deer.

The body weight increased on average by $9.6 \mathrm{~kg}$ in the groups with higher protein content in the diet and with the modified day length and by only $6.7 \mathrm{~kg}$ in the control group (III). Appropriate conditions provided to animals during winter are essential, as confirmed by experiments conducted by Olguin et al. (2013), Gaspar-López et al. (2011), Janiszewski et al. (2008) and in the present study.

Similarly, the antler weight depended on the conditions provided to the animals during the winter period. However, the greatest effect was exerted by the protein content in the diet, adequate supplementation, and milder wintering conditions. In turn, 
the extended day length accelerated development of antlers and velvet loss; hence, the antlers in this group exhibited the lowest weight. This phenomenon was confirmed by Suttie et al. (1991) as well as Suttie and Webster (1995).

\section{Conclusion}

In conclusion, an appropriate level of total protein and supplementation of the stag nutrition had a positive effect on animal fitness and antler growth. Time had the greatest effect on selected haematological parameters and mineral content in farm fallow deer plasma. The differences were mainly observed between the 2016 and 2017 measurements for $\mathrm{RBC}, \mathrm{Zn}, \mathrm{Mg}, \mathrm{Cu}, \mathrm{Ca}$ and $\mathrm{Fe}$. In contrast, the equations between the measurements were in the first year of testing only in the case of $\mathrm{Mg}$ concentration, while in the second year in the case of $\mathrm{Ca}$. Generally, prolonged repeated of breeding treatments give a greater effect. The effect of time and protein interaction had on WBC and $\mathrm{Zn}$, while the effect of time and light interaction on $\mathrm{WBC}, \mathrm{Zn}, \mathrm{Mg}, \mathrm{Ca}$. Increased protein supply, separately, in the fallow deer diet causes an increase in the concentration of $\mathrm{P}, \mathrm{Mg}, \mathrm{Cu}$ and $\mathrm{Ca}$ in their plasma, while the extension of the light day has a positive effect on the content of RCB, HGB, $\mathrm{P}, \mathrm{Mg}, \mathrm{Cu}$ and $\mathrm{Ca}$. On the other hand, the reduction in the quality of wintering conditions for animals was marked by an increase in WBC (Table 10). Therefore it can be assumed that the results of the present study have not only a theoretical but also application value.

Table 10. Summary of results obtained

\begin{tabular}{|c|c|c|c|c|c|c|}
\hline \multirow[t]{2}{*}{$\begin{array}{c}\text { Analyzed } \\
\text { variable }\end{array}$} & \multicolumn{2}{|c|}{$\begin{array}{c}\text { Group I } \\
\text { Total protein content of } \\
16 \% \text {, natural length of the } \\
\text { daylight }\end{array}$} & \multicolumn{2}{|c|}{$\begin{array}{c}\text { Group II } \\
\text { Total protein content of } \\
16 \%, \text { artificially extended } \\
\text { daylight }\end{array}$} & \multicolumn{2}{|c|}{$\begin{array}{c}\text { Group III } \\
\text { Total protein content of } \\
10 \% \text {, natural length of the } \\
\text { daylight }\end{array}$} \\
\hline & 2016 & 2017 & 2016 & 2017 & 2016 & 2017 \\
\hline WBC & $\approx$ & $\approx$ & $\approx$ & $\approx$ & $\approx$ & $\Delta$ \\
\hline $\mathrm{RBC}$ & $\nabla$ & $\approx$ & $\approx$ & $\Delta$ & $\approx$ & $\approx$ \\
\hline HGB & $\approx$ & $\approx$ & $\approx$ & $\Delta$ & $\approx$ & $\approx$ \\
\hline HCT & $\boldsymbol{\nabla}$ & $\approx$ & $\approx$ & $\approx$ & $\approx$ & $\approx$ \\
\hline $\mathrm{Zn}$ & $\approx$ & $\nabla$ & $\approx$ & $\approx$ & $\approx$ & $\approx$ \\
\hline $\mathrm{P}$ & $\approx$ & $\nabla$ & $\Delta$ & $\approx$ & $\Delta$ & $\approx$ \\
\hline $\mathrm{Mg}$ & $\approx$ & $\Delta$ & $\Delta$ & $\approx$ & $\Delta$ & $\approx$ \\
\hline $\mathrm{Cu}$ & $\Delta$ & $\Delta$ & $\Delta$ & $\approx$ & $\Delta$ & $\approx$ \\
\hline $\mathrm{Ca}$ & $\approx$ & $\approx$ & $\Delta$ & $\boldsymbol{\nabla}$ & $\approx$ & $\boldsymbol{\nabla}$ \\
\hline $\mathrm{Fe}$ & $\approx$ & $\approx$ & $\approx$ & $\approx$ & $\approx$ & $\approx$ \\
\hline Body weight & \multicolumn{2}{|c|}{$\Delta$} & \multicolumn{2}{|c|}{$\Delta$} & \multicolumn{2}{|c|}{$\Delta$} \\
\hline Mass of antler & \multicolumn{2}{|c|}{$\Delta$} & \multicolumn{2}{|c|}{$\Delta$} & \multicolumn{2}{|c|}{$\boldsymbol{\Delta}$} \\
\hline
\end{tabular}

$\boldsymbol{\Delta}$ - significant increase, $\boldsymbol{\nabla}$ - significant decrease, $\approx$ - no significant change

In future research, it is planned to take blood from deer more often and determine hematology and mineral levels to capture more accurate changes over time. In addition, an identical artificial lighting plan should be used. In addition, as recommended by other researchers (Felton et al., 2018) to assess digestibility protein and energy both in 
vivo and in vitro. Estimations of protein- and energy-digestibility are problematic to extrapolate to the population level, because of complex interactions between diet and individual, and many of the studies were compiled at the population level. Furthermore, in the case of research into small ruminants, a constant supply of drinking water should be ensured in pasture management (Fischer et al., 2017), which would also be worth to check in moderate climate conditions.

\section{REFERENCES}

[1] Asher, G. W. (1993): Growth and Feeding Management of farmed Fallow Deer in New Zealand. - In: Asher, G. W. (ed.) Procs. First World Forum on Fallow Deer Farming. Mudgee, NSW, Australia.

[2] Asher, G. W., Peterson, A. J., Bass, J. J. (1989): Seasonal pattern of LH and testosterone secretion in adult male fallow deer (Dama dama). - Journal of Reproduction and Fertility 85: 657-665.

[3] Bandy, P. J., Mc, T. I., Cowan Wood, A. J. (1970): Comparative growth in four races of black tailed deer (Odocoileus hemionus). Part 1. Growth in body weight. - Canadian Journal of Zoology 48: 1401-1410.

[4] Bao, K., Li, G. Y., Cui, X. Z. (2010): Effects of different copper sources on serum biochemical parameters and nutrient digestibilities in growing male sika deer (Cervus nippon). - Chinese Journal of Animal Nutrition 22: 717-722.

[5] Bartoskewitz, M. L., Hewitt, D. G., Laurenz, J. C. (2007): Effect of dietary copper and zinc concentrations on white-tailed deer antler growth, body size, and immune system function. - Small Ruminant Research 73: 87-94.

[6] Bubenik, G. A. (2006): Seasonal regulation of deer reproduction as related to the antler cycle - a review. - Veterinarski Arhive 76: 275-285.

[7] Bubenik, G. A., Bubenik, A. B., Zamecnik, J. (1979): The development of circannual rhythm of estradiol in plasma of male white-tailed deer (Odocoileus virginianus). Comparative Biochemistry and Physiology Part A: Physiology 62A: 869-872.

[8] Bubenik, G. A., Miller, K. V., Lister, A. L., Osborn, D. A., Bartoš, L., Van Der Kraak, G. J. (2005): Testosterone and estradiol concentrations in serum, velvet skin and growing antler bone of male white-tailed deer. - Journal of Experimental Zoology 303A: 186-192.

[9] DelGiudice, G. D., Mech, L. D., Kunkel, K. E., Gese, E. M., Seal, U. S. (1992): Seasonal patterns of weight, hematology and serum characteristics of free-ranging female whitetailed deer in Minnesota. - Canadian Journal of Zoology 70: 974-983.

[10] Dryden, G. M. (2011): Quantitative nutrition of deer: energy, protein and water. - Animal Production Science 51(4): 292-302.

[11] Dryden, G. M. (2016): Nutrition of antler growth in deer. - Animal Production Science 56(6): 962-970.

[12] Elliott, J. L., Oldham, J. M., Asher, G. W., Molan, P. C., Bass, J. J. (1996): Effect of testosterone on binding of Insulin - like growth factor I (IGF-1) nad IGF - II in growing antlers of fallow deer (Dama dama). - Growth Regulation 6(4): 214-21.

[13] Felton, A. M., Wam, H. K., Stolter, C., Mathisen, K. M., Wallgren, M. (2018): The complexity of interacting nutritional drivers behind food selection - a review of northern cervids. - Ecosphere 9(5): e02230. DOI: 10.1002/ecs2.2230.

[14] Fischer, A., Kaiser, T., Pickert, J., Behrendt, A. (2017): Studies on drinking water intake of fallow deer, sheep and mouflon under semi-natural pasture conditions. - Grassland Science 63(1): 46-53.

[15] French, C. E., McEwen, L. C., Magruger, N. D., Rader, T., Long, T. A., Swift, R. W. (1960): Responses of white-tailed bucks to added artificial light. - Journal of Mammalogy 41: 23-29. 
[16] Gaspar-López, E., Landete-Castillejos, T., Estevez, J. A., Ceacero, F., Gallego, L. (2010): Biometrics, testosterone, cortisol and antler growth cycle in Iberian red deer stags (Cervus elaphus hispanicus). - Reproduction in Domestic Animals 45: 243-249.

[17] Gaspar-López, E., Landete-Castillejos, T., Estevez, J. A., Ceacero, F., Gallego, L., Garcia, A. J. (2011): Seasonal variations in red deer (Cervus elaphus) hematology related to antler growth and biometric measurements. - Journal of Experimental Zoology 315: 242-249.

[18] Gordon, A. S., Zanjani, E. D., Levere, R. D., Kappas, A. (1970): Stimulation of mammalian erythropoiesis by $5 \beta-\mathrm{H}$ steroid metabolites. - Proceedings of the National Academy of Sciences of the United States of America 65: 919-924.

[19] Goss, R. J. (1969): Photoperiodic control of antler cycles in deer. 1. Phase shift and frequency changes. - Journal of Experimental Zoology 170: 311-324.

[20] Jaczewski, Z. (1954): The effect of changes in length of daylight on the growth of antlers in deer (Cervus elaphus L.). - Folia Biologica 2: 133-143.

[21] Janiszewski, P., Dmuchowski, B., Gugołek, A., Żełobowski, R. (2008): Body weight characteristics of farm-raised fallow deer (Dama dama L.) over the winter period. Journal of Central European Agriculture 9(2): 337-342.

[22] Kováč, G., Ciberej, J., Paulíková, I., Seidel, H. (1997): Haematological indices in fallow deer. - Acta Veterinaria Brno 66: 203-211.

[23] Kuba, J. (2014): Analysis of changes in the concentration of $\mathrm{Ca}, \mathrm{P}$ and $\mathrm{Mg}$ in blood serum of red deer (Cervus elaphus) immature males in farm breeding. - Acta Scientiarum Polonorum Zootechnica 13(2): 31-40.

[24] Kučer, N., Kuleš, J., Barić Rafaj, R., Tončić, J., Vicković, I., Štokovic, D., Potočnjak, D., Šsštaric, B. (2013): Mineral concentrations in plasma of young and adult red deer. Veterinarski Arhive 83(4): 425-434.

[25] Kun, B., Weili, S., Chunyi, L., Kaiying, W., Zhipeng, L., Shidan, B., Guangyu, L. (2015): Effects of dietary zinc supplementation on nutrient digestibility, haematological biochemical parameters and production performance in male sika deer (Cervus nippon). Animal Production Science 56(6): 997-1001.

[26] Landete-Castillejos, T., García, A. J., Gómez, J. A., Laborda, J., Gallego, L. (2002): Effects of nutritional stress during lactation on immunity costs and indices of future reproduction in Iberian red deer (Cervus elaphus hispanicus). - Biology Reproduction 67: 1613-1620.

[27] Landete-Castillejos, T., Estévez, J. A., Martínez, A., Ceacero, F., García, A. J., Gallego, L. (2007): Does chemical composition of antler bone reflect the physiological effort made to grow it? - Bone 40: 1095-1102.

[28] Marell, A., Hofgaard, A., Danell, K. (2006): Nutrient dynamics of reindeer forage species along snowmelt gradients at different ecological scales. - Basic and Applied Ecology 7: 13-30.

[29] McEwan, E. H. (1968): Growth and development of barren-ground caribou. - Canadian Journal of Zoology 46: 1023-1029.

[30] Nelson, J. E. (2004): Infrared methods for daylight acquisition of leo satellites. - Thesis. Captain, USAF, Washington, DC.

[31] Olguin, C. A., Landete-Castillejos, T., Ceacero, F., García, A. J., Gallego, L. (2013): Effects of Feed Supplementation on Mineral Composition, Mechanical Properties and Structure in Femurs of Iberian Red Deer Hinds (Cervus elaphus hispanicus) - PLoS One 8(6): e65461.

[32] Padilla, S., Bouda, J., Quiroz-Rocha, G. F., Davalos, J. L., Sanches, A. (2000): Biochemical and haematological values in venous blood of captive red deer (Cervus elaphus) at high altitude. - Acta Veterinaria Brno 69: 327-331.

[33] Pollock, A. M. (1975): Seasonal changes in appetite and sexual condition in red deer stags maintained on a six month photoperiod. - The Journal of Physiology 244: 95P-96P. 
[34] Richardson, C., Lionberger, J., Miller, G. (2008): White-Tailed Deer Management in the Rolling Plains of Texas. - Texas Parks and Wildlife Department, Austin, TX.

[35] Sempere, A. J., Mauget, R., Bubenik, G. A. (1992): Influence of photoperiod on the seasonal pattern of secretion of luteinizing hormone and testosterone and on the antler cycle in roe deer (Capreolus capreolus). - Journal of Reproduction and Fertility 95: 693700 .

[36] Simpson, A. M., Suttie, J. M., Kay, R. N. B. (1983/84): The influence of artificial photoperiod on the growth, appetite and reproductive status of male red deer and sheep.Animal Reproduction Science 6: 291-299.

[37] Snyder, D., Cowan, R., Hagen, D. R., Schanbacher, B. D. (1983): Effect of pinealectomy on seasonal changes in antler growth and concentration of testosterone and prolactin in white-tailed deer. - Biology of Reproduction 29: 63-71.

[38] Suttie, J. M., Simpson, A. M. (1985): Photoperiodic Control of Appetite, Growth, Antlers and Endocrine Status of Red Deer. - In: Fennessy, P. F., Drew, K. R. (eds.) Biology of Deer Production. The Royal Society of New Zealand, Wellington.

[39] Suttie, J. M., Webster, J. R. (1995): Extreme seasonal growth in Arctic deer: comparisons and control mechanisms. - American Zoologist 35: 215-221.

[40] Suttie, J. M., Lincoln, G. A., Kay, R. N. B. (1984): Endocrine control of antler growth in red deer stags. - Journal of Reproduction and Fertility. 71: 7-15.

[41] Suttie, J. M., Fennesy, P. F., Crosbie, S. F., Corson, I. D., Laas, F. J., Elgar, H. J., Lapwood, K. R. (1991): Temporal changes in LH and testosterone and their relationship with the first antler in red deer (Cervus elaphus) stags from 3 to 15 months of age. Journal of Endocrinology 131(3): 467-74.

[42] Suresh, C., Das, A., Katole, S., Saini, M., Swarup, D. (2013): Effect of concentrate supplementation on feed consumption, nutrient utilization and blood metabolite profile in captive spotted deer (Axis axis) fed oat (Avena sativa) and berseem (Trifolium alexandrinum) fodders based diet. - Zoo Biology 32(2): 195-203.

[43] Tajchman, K. (2019): Selected haematological indices in farmed male fallow deer (Dama dama) depending on the different conditions during the wintering period. - Veterinarni Medicina 64: 379-385.

[44] Tomkins, N. W., McMeniman, N. P., Daniel, R. C. W. (1991): Voluntary feed intake and digestibility by red deer (Cervus elaphus) and sheep (Ovis ovis) of pangola grass (Digitaria decumbens) with or without a supplement of leucaena (Leucaena leucocephala). - Small Ruminant Research 5(4): 337-345.

[45] Ullrey, D. E. (1982): Nutrition and Antler Development in White-Tailed Deer. - In: Brown, R. D. (ed.) Antler Development in Cervidae. Caesar Kleberg Wildlife Research Institute, Kingsville, TX.

[46] Ullrey, D. E., Youatt, W. G., Johnson, H. E., Fay, L. D., Bradley, B. L. (1967): Protein requirements of white-tailed deer fawns. - Journal of Wildlife Management 31: 679-685.

[47] Wam, H. K., Histol, T., Nybakken, L., Solberg, E. J., Hjeljord, €. O. (2016): Transient nutritional peak in browse foliage after forest clearing advocates cohort management of ungulates. - Basic and Applied Ecology 17: 252-261.

[48] Weiss, D. J., Wardrop, K. J. (2010): Schalm's Veterinary Hematology. Sixth Ed. Blackwell Publishing, Ames, IA. 